\title{
Continuous silicon oxycarbide fiber mats with tin nanoparticles as high capacity anode for lithium-ion batteries
}

\author{
Aura Tolosa, ${ }^{1,2}$ Mathias Widmaier, ${ }^{2,3}$ Benjamin Krüner, ${ }^{1,2}$ \\ John M. Griffin, ${ }^{4}$ and Volker Presser ${ }^{1,2^{*}}$ \\ 1 INM - Leibniz Institute for New Materials, Campus D2 2, 66123 Saarbrücken, Germany \\ 2 Department of Materials Science and Engineering, Saarland University, Campus D2 2, 66123 Saarbrücken, Germany \\ 3 Robert Bosch GmbH, Robert-Bosch-Campus 1, 71272 Renningen, Germany \\ 4 Department of Chemistry, Lancaster University, Lancaster, LA1 4YB, United Kingdom \\ * Corresponding author's eMail: volker.presser@leibniz-inm.de
}

\begin{abstract}
Continuous fiber mats are attractive electrodes for lithium-ion batteries, because they allow operation at high charge/discharge rates in addition to be free of polymer binder and conductive additive. In this work, we synthesize and characterize continuous $\mathrm{Sn} / \mathrm{SiOC}$ fibers (diameter ca. $0.95 \mu \mathrm{m}$ ), as Li-ion battery anode. Our synthesis employs electrospinning of a low-cost silicone resin, using tin acetate in a dual role both as a polymer crosslinker and tin precursor (6-22 mass\%). The hybrid electrodes present very high initial reversible capacities $\left(840-994 \mathrm{mAh} \cdot \mathrm{g}^{-1}\right)$ at $35 \mathrm{~mA} \cdot \mathrm{g}^{-1}$, and retain $280-310 \mathrm{mAh} \cdot \mathrm{g}^{-1}$ at $350 \mathrm{~mA} \cdot \mathrm{g}^{-1}$. After $100 \mathrm{cycles}$ at $70 \mathrm{~mA} \cdot \mathrm{g}^{-1}$, the hybrid fibers maintained 400-509 $\mathrm{mAh} \cdot \mathrm{g}^{-1}$. Adding low amounts of $\mathrm{Sn}$ is beneficial not just for the crosslinking of the polymer precursor, but also to decrease the presence of electrochemically inactive silicon carbide domains within the SiOC fibers. Also, the metallic tin clusters contribute to a higher $\mathrm{Li}^{+}$insertion in the first cycles. However, high amounts of $\mathrm{Sn}$ decrease the electrochemical performance stability. In SiOC fibers synthesized at high temperatures $\left(1200{ }^{\circ} \mathrm{C}\right)$, the $\mathrm{C}_{\text {free }}$ phase has a significative influence on the stability of the system, by compensating the volume expansion from the alloying systems $\left(\mathrm{Sn}, \mathrm{SiO}_{2}\right)$, and improving the conductivity of the hybrid system. Therefore, a high amount of carbon, and a high graphitization degree is crucial for a high conductivity and a stable electrochemical performance.
\end{abstract}

\section{Keywords:}

Silicon oxycarbide; electrospinning; lithium-ion battery; silicone resin; tin nanoparticles 


\section{Introduction}

To meet the growing requirements for mobile electrochemical energy storage, ${ }^{1}$ it is important to advance present-day electrode materials both in regard to charge/discharge rates (power) and storage capacity (energy). ${ }^{2}$ Li-ion batteries (LIBs) present high energy density, being today the main choice for consumer electronics and electrical or hybrid vehicles. ${ }^{3}$ To further improve the capacity of LIBs, significant efforts have been dedicated to replace graphite anodes (theoretical capacity $\approx 372 \mathrm{mAh} \cdot \mathrm{g}-$ $\left.{ }^{1}\right)$ by other elements from the group IV (Si, Sn, and Ge; cf. Ref. ${ }^{4}$ ) which undergo alloying reactions with lithium leading to high capacity values $\left(4200,1627\right.$, and $993 \mathrm{mAh} \cdot \mathrm{g}^{-1}$ theoretical capacity of Si, Ge, and Sn, respectively). ${ }^{5}$ Such high capacities are accomplished not without complications; for example, in case of silicon, a complete lithiation ( $\mathrm{Li}_{22} \mathrm{Si}_{5}$ alloy) corresponds to a volumetric expansion of about $400 \%,{ }^{6}$ leading to poor cycling and huge capacity fading. To improve the specific capacity and cycle life of anode materials, nanoparticles of $\mathrm{Si}, \mathrm{Sn}$, or $\mathrm{Ge}$, have been synthesized in a carbon matrix ${ }^{5,6}$ to compensate the volumetric changes (volume expansion of graphite $\approx 10 \%)^{5}$ and to improve the electrical conductivity of the system. These $\mathrm{Si} / \mathrm{C}$ composite materials present a theoretical maximum capacity of $712 \mathrm{mAh} \cdot \mathrm{g}^{-1}$, corresponding to 11.7 mass $\% \mathrm{Si}$, at which the volumetric expansion of $\mathrm{Si}$ can be compensated by the presence of pores, without decreasing the volumetric. ${ }^{6}$

Since early work of Wilson and Dahn, ${ }^{7}$ polymer-derived SiOC materials have been investigated as an alternative to $\mathrm{Si} / \mathrm{C}$ composites due to the lower cost for synthesis, high capacity values (between 500$\left.900 \mathrm{mAh} \cdot \mathrm{g}^{-1}\right)$, and reduced capacity fading. ${ }^{6,8}$ Polymer-derived SiOC synthesized at $1000-1800{ }^{\circ} \mathrm{C}$ is predominately amorphous and consists of Si-O-C nanodomains engulfed by carbon. ${ }^{9}$ The latter is called free carbon $\left(C_{\text {free }}\right)$, that is carbon beyond the stoichiometric amount necessary to saturate all the $\mathrm{Si}$ valences. ${ }^{9}$ The Si-O-C nanodomains consist of amorphous silica, and $\mathrm{SiC}_{x} \mathrm{O}_{4-x}$ tetrahedral units (with $1 \leq x \leq 4) .{ }^{9}, 10$ The microstructure and composition of SiOC depends on the precursor material and the pyrolysis temperature. Above $1000^{\circ} \mathrm{C}$, carbon segregates and forms turbostratic graphite which encapsulates silica domains with local precipitation of SiC by local carbothermal reduction. ${ }^{9}$ Riedel et al. have demonstrated the effect of the composition and microstructure of SiOC powder electrodes in the electrochemical performance as anodes for LIBs. ${ }^{11-13}$ Using a polysiloxane as precursor (polyramic RD-684a), samples pyrolyzed at $900{ }^{\circ} \mathrm{C}$ presented the highest initial reversible capacity (738 $\left.\mathrm{mAh} \cdot \mathrm{g}^{-1}\right)$, but suffered from strong capacity fading. ${ }^{13}$ At higher synthesis temperature, the stability of the system is improved, with an optimum for samples pyrolyzed at $1100{ }^{\circ} \mathrm{C}$ for $3 \mathrm{~h}$ with a lower initial reversible capacity $\left(532 \mathrm{mAh} \cdot \mathrm{g}^{-1}\right) \cdot{ }^{13}$ Adding divinylbenzene to the polysiloxane precursor leads to an increase in the carbon content of the SiOC. ${ }^{8}$ It was found that SiOC behaves as a hybrid material, consisting of disordered Si-O-C nanodomains having a high first $\mathrm{Li}^{+}$insertion capacity of $1300^{\circ} \mathrm{mAh} \cdot \mathrm{g}^{-1}$, and $\mathrm{C}_{\text {free }}$ having an estimated capacity of $350^{\circ} \mathrm{mAh} \cdot \mathrm{g}^{-1}$ (Ref. ${ }^{8}$ ). Among these, the material with the highest reversible capacity and best cyclability contained 51 mass $\%$ Si-O-C nanodomains and 49 mass $\% \mathrm{C}_{\text {free. }}{ }^{8}$ 
The incorporation of commercially available or in-situ synthesized Si nanoparticles to SiOC has also been investigated, ${ }^{14,15}$ finding that the SiOC network helps to improve the conductivity of the system and buffers the volume change. ${ }^{15}$ Compared to pure SiOC synthesized at $1100{ }^{\circ} \mathrm{C}$ incorporating amorphous or crystalline Si leads to higher initial capacities, namely $704 \mathrm{mAh} \cdot \mathrm{g}^{-1}$ or $905 \mathrm{mAh} \cdot \mathrm{g}^{-1}$, respectively. ${ }^{14}$ After 30 cycles, the capacity of crystalline Si/SiOC fades below the capacity of pure SiOC, while the amorphous Si/SiOC maintained $85 \%$ of the capacity. ${ }^{14} \mathrm{Sn}$ nanoparticles have also been incorporated to low- and high-content carbon SiOC by mixing polysilsesquioxanes with tin(II) acetate, followed by pyrolysis at $1000{ }^{\circ} \mathrm{C} .{ }^{16}$ Adding 25 mass $\%$ of $\mathrm{Sn}$ increases the initial reversible capacity compared to the high- and low-carbon SiOC samples, by $9 \%$ and $140 \%$, respectively. ${ }^{16}$ The increase in capacity is related to the formation of $\mathrm{Li}_{22} \mathrm{Sn}_{5}$ and $\mathrm{Li}_{7} \mathrm{Sn}_{2}$, and the increase in rate handling and stability is attributed to the electrically conductive $C_{\text {free }}$ phase.${ }^{16} \mathrm{All}$ these studies on polymer-derived SiOC have employed polymer-bound powder electrodes.

Continuous fiber electrodes, free-standing and polymer binder free, are attractive because the continuous path for electron transport enables operation at much higher charge/discharge rates. ${ }^{17}$ Also, for hybrid fibers containing carbon and redox-active materials, no additional conductive additives are needed. ${ }^{18}$ The absence of inactive components (conductive additives and polymer binder) increases the overall gravimetric energy density of the electrode. So far, only continuous fibers have been fabricated by Zhang et al. using nanoparticles dispersed in a polyacrylonitrile (PAN) derived carbon matrix to obtain free-standing electrodes. ${ }^{19-21}$ The dispersed nanoparticles have been commercially available $\mathrm{Si}^{19-21} \mathrm{Ge}^{19}$ and $\mathrm{Sn},{ }^{19,22}$ or synthetized $\mathrm{SiOC}$, and $\mathrm{SiO}_{2}$ particles. ${ }^{21,}{ }^{23}$ The main issue of this synthesis process is that inorganic nanoparticles show a very high surface energy and tend to agglomerate in an organic medium. ${ }^{24}$ Therefore, the resulting material is inhomogeneous, affecting the material properties. To obtain homogeneous materials without the need for surface active agents it is better to employ approaches leading to the in-situ formation of nanodomains. ${ }^{24}$

In our past work, we have demonstrated electrospinning of SiOC electrospun fibers obtained from lowcost silicone resins. ${ }^{17}$ For this synthesis, one always needs a crosslinker, such as zirconium acetylacetonate or zinc acetylacetonate. ${ }^{17,25}$ However, parts of these crosslinkers remain in the system forming (undesired/unnecessary) metal compounds. ${ }^{26}$ We now have explored the direct use of a Sncontaining crosslinker to enable enhanced electrochemical performance of the resulting SiOC-Sncompound. According to the Ellingham diagrams, ${ }^{27}$ the Gibbs free energy of $\mathrm{SiO}_{2}$ between $900-1300{ }^{\circ} \mathrm{C}$ is lower than $\mathrm{SnO}_{2}$; therefore, $\mathrm{SiO}_{2}$ acts as a reducing agent for $\mathrm{SnO}_{2}$, leading to the formation of metallic Sn domains. In this study, we evaluate for the first-time polymer-derived SiOC-Sn fibers as anode materials for LIBs. The process variables correspond to pyrolysis temperature $\left(1000-1200^{\circ} \mathrm{C}\right)$ and Sn-containing crosslinker amount (5-20 mass\%). The effect of the process variables in the material properties and electrochemical performance is evaluated. 


\section{Experimental description}

\subsection{Materials synthesis}

The solvents trichlormethane (TCM, Stabilized, GPR Rectapur) and N,N-dimethylformamide (DMF; anhydrous, $99.8 \%)$ were purchased from VWR Chemicals and Sigma Aldrich, respectively. The polymers, silicone resin namely $\mathrm{H} 44$ (polymethylphenyl-silsesquioxane) and polyvinylpyrrolidone (PVP, $M w \approx 1,300,000 \mathrm{~g} \cdot \mathrm{mol}^{-1}$ ) were purchased from Wacker Chemie and Sigma Aldrich, respectively. Moisture sensitive tin(II) acetate (SnAc) was purchased from Sigma Aldrich and stored in moisture free nitrogen atmosphere in a glove box $\left(\mathrm{H}_{2} \mathrm{O}, \mathrm{O}_{2}<0.1 \mathrm{ppm}\right)$. All chemicals were used as-received.

The synthesis of SiOC fibers is based on the approach followed in past studies, ${ }^{17}$ but modified using PVP to improve rheological behavior for electrospinning. ${ }^{25} 30$ mass\% polymer (75:25 mass ratio of $\mathrm{H} 44: \mathrm{PVP}$ ) solutions were prepared in 1:1 volumetric ratio of TCM:DMF. After the polymers were completely dissolved, the SnAc was added and stirred for $1 \mathrm{~h}$ before electrospinning. SnAc was added in different amounts: $2.5,4.5$, and 9.0 mass\%. These amounts correspond to stoichiometric ratios of $0.05,0.1$, and $0.2 \mathrm{~mol}$ of Sn per $1 \mathrm{~mol}$ of Si.

Electrospinning was carried out with a MECC Co. NF-103V nanofiber system. The spinning dope (5 mL) was pumped at $1 \mathrm{~mL} \cdot \mathrm{h}^{-1}$ through a spinneret (inner diameter: $510 \mu \mathrm{m}$ ) which was inductively charged at $28 \mathrm{kV}$. The fibers were collected on a stationary grounded target at $21 \mathrm{~cm}$ from the spinneret. The spinneret head moved parallel to the collector with a travel distance of $10 \mathrm{~cm}$ at a travel velocity $2 \mathrm{~cm} \cdot \mathrm{s}^{-1}$. The collected material was then heated at $100^{\circ} \mathrm{C}$ for $24 \mathrm{~h}$ to stabilize the fiber shape. The pyrolysis of the crosslinked silicone resin was achieved by heating the material at $5^{\circ} \mathrm{C} \cdot \mathrm{min}^{-1}$ to $200^{\circ} \mathrm{C}$ for $2 \mathrm{~h}$. and later to $1000^{\circ} \mathrm{C}$ or $1200^{\circ}$ under argon in a graphite heater (Thermal Technologies, Model $1100 \mathrm{C}$ ) for $2 \mathrm{~h}$. After heat treatment, non-woven SiOC fiber mats were cooled to room temperature at a rate of $20^{\circ} \mathrm{C} \cdot \mathrm{min}^{-1}$. The $\mathrm{Sn} / \mathrm{SiOC}$ fiber mats were named according to the added $\mathrm{Sn}$ content $(0.05 \mathrm{Sn}$, $0.1 \mathrm{Sn}$, or $0.2 \mathrm{Sn})$ and the pyrolysis temperature $(-1000$ or -1200$)$.

$\mathrm{SiOC}$ was also produced without a Sn precursor, as a monolith using the same procedure and thermal treatment used for the spinning dope preparation, but without the addition of SnAc. Also, a monolith containing $0.05 \mathrm{Sn}$ was prepared for comparison of the electrochemical performance. These monoliths with and without Sn were named as M-0.05 Sn and M-SiOC, respectively, and according to the pyrolysis temperature $(-1000$ or -1200$)$.

\subsection{Materials characterization}

\subsubsection{Structural and chemical characterization}

The morphology of the fibers was examined by scanning electron microscopy using a JEOL JSM 7500F field emission scanning electron microscope (FE-SEM). For imaging, the fiber mats were fixed to a steel sample holder with sticky carbon tape. The as-spun fibers were coated with a thin layer of platinum in 
a JEOL Autofine Coater. The fiber diameter correspond to the average diameter of at least 100 fibers, measured from the SEM images by ImageJ software. ${ }^{28}$ Elemental composition of the fibers was analyzed by EDX using a X-Max 150 detector from Oxford Instruments attached to the SEM chamber. Under $10 \mathrm{kV}$ of acceleration voltage and $10 \mu \mathrm{A}$ of emission current, the spectra of at least ten fibers were acquired and average values were calculated.

Transmission electron microscopy (TEM) was done with a JEOL JEM-2100F system operating at $200 \mathrm{kV}$ in vacuum. Ground fiber mats were dispersed and sonicated in ethanol, and drop casted in copper grid with carbon film. Energy dispersive X-ray spectroscopy (EDX) point analysis were performed using a Thermo Scientific MC100021 detector attached to the TEM chamber. The spectra were acquired at $200 \mathrm{kV}$ and 2 min exposition for point analysis.

To characterize the chemical composition of the system Fourier-transform infrared spectroscopy (FTIR), and nuclear magnetic resonance spectroscopy (NMR) were used. FT-IR was performed with a diamond total attenuated reflectance crystal (ATR) using a Bruker Tensor 27 system. Raman spectra were measured using a Renishaw InVia Raman system, and a green laser (532 nm excitation wavelength) with $0.5 \mathrm{~mW}$ power on the sample, using a spectral resolution of ca. $1.2 \mathrm{~cm}^{-1}$ and a $50 \mathrm{x}$ objective (numeric aperture: 0.9). X-ray diffraction (XRD) was conducted employing a D8 Advance diffractometer (Bruker AXS) with a copper X-ray source (Cu-Ka, $40 \mathrm{kV}, 40 \mathrm{~mA})$ in point focus $(0.5 \mathrm{~mm})$ and a Goebel mirror. A VANTEC-500 (Bruker AXS) 2D detector ( $25^{\circ}$ per step; measurement time 1000 s per step) was employed. The samples were grinded and placed on a Si-wafer. Solid-state magicangle spinning (MAS) NMR measurements were performed on Bruker Avance III spectrometers operating at magnetic field strengths of $9.4 \mathrm{~T}\left({ }^{13} \mathrm{C}\right)$ and $16.4 \mathrm{~T}\left({ }^{29} \mathrm{Si}\right)$. The MAS frequency for all experiments was $12.5 \mathrm{kHz}$. All experiments were performed with direct polarization using a $90^{\circ}$ acquire pulse sequence. A recycle interval of $15 \mathrm{~s}$ was used for all experiments. Chemical shifts were referenced to the $\mathrm{CH}_{3}$ resonance of $\mathrm{L}$-alanine at $20.5 \mathrm{ppm}$ for ${ }^{13} \mathrm{C}$ and kaolinite $\left(\mathrm{Al}_{2} \mathrm{Si}_{2} \mathrm{O}_{5}(\mathrm{OH})_{4}\right)$ at $91.2 \mathrm{ppm}$ for ${ }^{29} \mathrm{Si}$.

Thermogravimetric measurements combined with a mass spectrometer (TGA-MS) were performed for the as-spun samples, using a STA 449 F3 Jupiter and QMS 403C Aëolos from Netzsch. The samples were heated to $1200^{\circ} \mathrm{C}$ at $5{ }^{\circ} \mathrm{C} \cdot \mathrm{min}^{-1}$ under $\mathrm{N}_{2}$. Analysis of the tin content was performed by inductively coupled plasma atomic emission spectroscopy (ICP-AES). The samples $(30 \mathrm{mg}$ ) were placed into microwave vessels, mixed with $6 \mathrm{~mL}$ of $\mathrm{HNO}_{3}, 4 \mathrm{~mL}$ of $\mathrm{H}_{2} \mathrm{SO}_{4}$, and $3 \mathrm{~mL}$ of $\mathrm{HF}$. The vessels were maintained at $150{ }^{\circ} \mathrm{C}$ with a pressure of $300 \mathrm{kPa}$ for several days until a homogenous liquid solution was observed. After cooling, the samples were placed into $50 \mathrm{~mL}$ polyethylene flasks and filled to the calibration mark for the inductively coupled plasma atomic emission spectroscopy (ICP-AES) using a Horiba Jobin Yvon Ultima2 system. 


\subsubsection{Electrochemical measurements}

SiOC fiber mats were tested as anodes for Li-ion batteries. The measurements were performed in custom-built polyether ether ketone (PEEK) cells with spring loaded titanium pistons as a threeelectrode system. ${ }^{29}$ The SiOC electrodes were punched out as $8 \mathrm{~mm}$ diameter discs $(\approx 3.5 \mathrm{mg}, 150 \mu \mathrm{m}$ thickness), and tested versus a lithium disc (11 mm diameter) as counter electrode. Working and counter electrode were separated by a glass fiber separator (13 mm diameter; GF/D from Whatman) and placed between $12 \mathrm{~mm}$ copper foil disc current collector ( $0.025 \mathrm{~mm}$ thickness, $99.8 \%$, Alfa Aesar). After assembling (without the lithium disc), the cells were dried at $2 \mathrm{kPa}, 120^{\circ} \mathrm{C}$ for $12 \mathrm{~h}$. After cooling, the cells were placed in an argon-filled glove box (MBraun Labmaster 130, $\mathrm{O}_{2}$ and $\mathrm{H}_{2} \mathrm{O}<1 \mathrm{ppm}$ ), and the lithium disc was placed in the corresponding position. After closing the cell, a piece of glass fiber (GF/D from Whatman) followed by a lithium wire (reference electrode) was inserted from the side in the electrolyte reservoir. The cell was filled with $60 \mu \mathrm{L}$ of $1 \mathrm{M}$ lithium hexafluorophosphate $\left(\mathrm{LiPF}_{6}\right)$ in electrochemical grade ethylene carbonate and dimethylcarbonate $1: 1$ by mass (EC/DMC) from BASF as electrolyte.

The sheet resistance of the fiber mats was measured with a custom-built spring-loaded four-point probe with blunt gold contacts (tip diameter: $1.5 \mathrm{~mm}$, tip distance: $3 \mathrm{~mm}$ ). Cyclic voltammetry (CV) was performed using a VSP300 potentiostat/galvanostat (Bio-Logic) and for galvanostatic cycling with potential limitation (GCPL) an Astrol BatSmall battery analyzer was used. For rate capability measurements, the cells were subjected to GCPL between $+0.05 \mathrm{~V}$ to $+3.0 \mathrm{~V} \mathrm{vs}$. $\mathrm{Li}^{\prime} \mathrm{Li}^{+}$at different current rates. Based on a material capacity of $700 \mathrm{mAh} \cdot \mathrm{g}^{-1}$, different specific currents were applied, starting at $35 \mathrm{~mA} \cdot \mathrm{g}^{-1}(0.05 \mathrm{C})$ for 5 cycles, followed by GCPL at $70 \mathrm{~mA} \cdot \mathrm{g}^{-1}(0.1 \mathrm{C})$ for 20 cycles, $140 \mathrm{~mA} \cdot \mathrm{g}$ ${ }^{1}(0.2 \mathrm{C}), 350 \mathrm{~mA} \cdot \mathrm{g}^{-1}(0.5 \mathrm{C}), 700 \mathrm{~mA} \cdot \mathrm{g}^{-1}(1 \mathrm{C})$ and $1400 \mathrm{~mA} \cdot \mathrm{g}^{-1}(2 \mathrm{C}), 10$ cycles each. Further GCPL was performed at $70 \mathrm{~mA} \cdot \mathrm{g}^{-1}$ for 40 cycles to complete $100 \mathrm{cycles}$. To evaluate the electrochemical performance in the first 5 cycles, the cells were tested by $\mathrm{CV}$ in the potential range between $+0.8 \mathrm{~V}$ to $+3.0 \mathrm{~V}$ vs. $\mathrm{Li} / \mathrm{Li}^{+}$at a scan rate of $0.1 \mathrm{mV} \cdot \mathrm{s}^{-1}$. From the GCPL data, the specific capacity $\left(C_{s p}\right)$ was calculated according to Eq. (1), by integrating the current between starting time $\left(t_{0}\right)$ and end time $(t)$ of the delithiation step, normalized to the total electrode mass $(m)$. Where the electrode mass corresponds to the mass of the $\mathrm{Sn} / \mathrm{SiOC}$ fiber mats, which are free of any polymer binder or any conductive additives.

$C_{s p}=\frac{\left(\int_{t_{0}}^{t} I d t\right)}{m}$

Polymer-bound electrodes were prepared for comparison. The produced monoliths ( $\mathrm{M}-\mathrm{SiOC}$ and $\mathrm{M}$ $0.05 \mathrm{Sn}$ ) were ground with an agate mortar in ethanol until obtaining a homogeneous slurry, to which 10 mass\% polytetrafluoroethylene (PTFE, 60 mass\% solution in water, Sigma Aldrich) and 5 mass\% carbon black Super C65 (Imerys Graphite \& Carbon) was added. The obtained paste was rolled until $126 \pm 7 \mu \mathrm{m}$ thick electrodes were obtained (MTI HR01 rolling machine, MTI). 


\section{Results and discussion}

\subsection{Polysilsesquioxane modified fibers}

To electrospin SiOC fibers derived from polysilsesquioxanes, one must employ a crosslinker to maintain the fiber shape during pyrolysis. Our previous work on electrospun SiOC fibers mats for electrochemical applications had used zinc acetylacetonate as a crosslinker. ${ }^{17}$ After pyrolysis, low amounts (5-10 mass\%) of zinc are present in the fibers. For this reason, we have replaced the zinc acetylacetonate by a Sn-containing crosslinker ( $\mathrm{SnAc}$ ) to not only benefit from the crosslinker activity during synthesis, but also to form electroactive Sn after pyrolysis to enhance the energy storage performance.

H44 is a commercially available polysilsesquioxane with the chemical formula described by Eq. (2), where -OR correspond to the functional groups where further crosslinking takes place.

$\left[\left(\mathrm{C}_{6} \mathrm{H}_{5}\right)_{0.62}\left(\mathrm{CH}_{3}\right)_{0.31}(\mathrm{OR})_{0.07} \mathrm{SiO}_{1.5}\right]_{n}$ where $\mathrm{OR}=-\mathrm{OH}$ and $-\mathrm{OC}_{2} \mathrm{H}_{5}$

In absence of metal alkoxides as crosslinkers or polymer modifiers, the condensation reactions described in Eq. (3-4) take place. In the presence of transition metal alkoxides, the metal alkoxide reacts following the reaction described by Eq. (5), exemplified for SnAc. ${ }^{16}$

$$
\begin{aligned}
& \equiv \mathrm{Si}-\mathrm{OH}+\mathrm{HO}-\mathrm{Si} \equiv \rightarrow \equiv \mathrm{Si}-\mathrm{O}-\mathrm{Si} \equiv+\mathrm{H}_{2} \mathrm{O} \\
& \equiv \mathrm{Si}-\mathrm{OH}+\mathrm{RO}-\mathrm{Si} \equiv \rightarrow \equiv \mathrm{Si}-\mathrm{O}-\mathrm{Si} \equiv+\mathrm{R}-\mathrm{OH} \\
& \equiv \mathrm{Si}-\mathrm{OH}+\mathrm{Sn}\left(\mathrm{CH}_{3} \mathrm{COO}\right)_{2} \rightarrow \mathrm{CH}_{3} \mathrm{COOSn}-\mathrm{O}-\mathrm{Si} \equiv+\mathrm{CH}_{3} \mathrm{COOH}
\end{aligned}
$$

Based on the reaction described in Eq. (5) and the number of crosslinking groups of the polymer, the minimum amount of Sn added was fixed to occupy most of the crosslinking positions, $0.05 \mathrm{~mol}$ of $\mathrm{Sn}$ per $1 \mathrm{~mol}$ of Si. Based on this proportion, an excess of Sn was added $(0.1 \mathrm{~mol}$ and $0.2 \mathrm{~mol}$ of Sn per $1 \mathrm{~mol}$ of Si). After electrospinning, the samples are named according to the Sn amount (0.05 Sn, $0.1 \mathrm{Sn}$, or $0.2 \mathrm{Sn}$ as spun), and after pyrolysis according to the tin content and the pyrolysis temperature (for example: $0.05 \mathrm{Sn}-1200)$.

The as-prepared spin dopes were electrospun and ultrafine fibers with smooth and uniform morphology were obtained, as confirmed by scanning electron micrographs (Figure 1A-B). The as-spun fibers had an average diameter of $1.64 \pm 0.30 \mu \mathrm{m}$ (Figure 1C). During electrospinning, the solvent evaporates, leaving behind the solid fibers conformed mainly by H44, containing PVP and SnAc.

The reactions in the as spun fibers during heating at $100{ }^{\circ} \mathrm{C}$ were characterized by FT-IR (Figure 1D). The infrared spectra show absorption bands of the $\mathrm{H} 44$ polymer: the Si-O stretching vibration of the Si-O-Si ladder-type structure appeared between $1040-1027 \mathrm{~cm}^{-1}$ (Ref. ${ }^{17}$ ), the band at $1128 \mathrm{~cm}^{-1}$ is related to phenolic groups, ${ }^{30}$ and the band at $1428 \mathrm{~cm}^{-1}$ comes from the $\mathrm{C}-\mathrm{H}$ vibration modes of the methyl groups. ${ }^{30}$ Absorbance of the bridging bond Si-C in the Si- $\mathrm{CH}_{3}$ was observed at $733 \mathrm{~cm}^{-1}$ (Ref. ${ }^{31}$ ). The absorption bands corresponding to acetate ligands are either very weak or non-observed. This can 
be related to the complete reaction of $\mathrm{Sn}$ in the Si-O-Sn and Sn-O-Sn network, forming volatile acetic acid. Absorption bands at $695 \mathrm{~cm}^{-1}$ and $928 \mathrm{~cm}^{-1}$ correspond to the stretching modes of $\mathrm{Sn}-\mathrm{O}$ and Si-OSi, respectively. ${ }^{16}$ Also, several signals of the PVP can be observed: the small peak at $1017 \mathrm{~cm}^{-1}$ corresponds to the $\mathrm{C}-\mathrm{C}$ polymer backbone and the band at $930 \mathrm{~cm}^{-1}$ is the breathing mode of the ring. ${ }^{26}$ The bands at $1270-1288 \mathrm{~cm}^{-1}$ emerge from the $\mathrm{C}-\mathrm{N}$ bonds in the polymer. ${ }^{32}$ Comparing the infrared spectra, no significant differences are observed when increasing the SnAc content. All spectra present similar peaks and confirm the formation of $\mathrm{Sn}-\mathrm{O}$ bonds, either between the Si-O-Si network, or forming separated Sn-O-Sn domains.

\section{2. $\mathrm{Sn} / \mathrm{SiOC}$ fibers}

After the fibers were completely crosslinked, the fibers were treated under Ar either at $1000^{\circ} \mathrm{C}$ or $1200{ }^{\circ} \mathrm{C}$ to form SiOC/Sn fibers. To understand the effect of the crosslinker during thermal treatment, thermogravimetric analysis with coupled mass spectrometry (TGA-MS) was carried in an inert atmosphere (Figure $1 \mathrm{E}-\mathrm{F}$ ). At $250{ }^{\circ} \mathrm{C}$, a mass loss of $4 \%$ is observed as water is being desorbed. At $300-$ $600{ }^{\circ} \mathrm{C}$, we see a drastic mass decrease due to redistribution reactions and the decomposition of the polysilsesquioxane. In this temperature range, initial exchange reactions between the bonds present in the crosslinked resin take place, forming volatile organosilicon species. ${ }^{33}$ Later, decomposition of the network occurs by bond-cleavage ${ }^{34}$ and methyl and phenyl groups diffuse through the bulk material. During the diffusion of the aliphatic and aromatic groups, some condense to form aromatic clusters which will be later seeds for carbon domains, while other leave as volatile compounds. Above $600{ }^{\circ} \mathrm{C}$, hydrogen gas is produced by the aromatic/turbostratic carbon domains, leading to a continuous mass loss of $5 \% .{ }^{34}$ After pyrolysis is completed, a total mass loss of $45 \%$ was obtained compared to the initial mass. The Sn-O-Sn domains initially form $\mathrm{SnO}$, which above $600{ }^{\circ} \mathrm{C}$ is not favored in presence of $\mathrm{C}$ and $\mathrm{Si}$ according to the Ellingham diagrams. ${ }^{27} \mathrm{SnO}$ is reduced to metallic tin, together with the release of hydrogen and $\mathrm{CO}$ upon ceramization, and it does not form either silicides or carbides. ${ }^{35}$

After pyrolysis, the fibers present a smooth surface with some beads present at the fiber surface and between the fibers as observed from the scanning electron micrographs (Figure 2). The material characterization data for the samples treated at $1000{ }^{\circ} \mathrm{C}$ are presented in the Supporting Information (Figure S1,S3). The amorphous fibers present an average diameter of $0.96 \pm 0.25 \mu \mathrm{m}$ after pyrolysis (Figure 3A). There are also some crystalline domains inside the fibers, as observed from the transmission electron micrographs (Figure 2). Also, the beads located outside the fibers present a crystalline structure engulfed by an amorphous matrix. EDX analysis was carried during TEM analysis (Supporting Information, Figure S2, Table S1), and we determined the clusters inside and outside the fibers to correspond with Sn covered by a SiOC shell. The size and distribution of Sn beads depends on the pyrolysis temperature and the used amount of SnAc, reaching diameter size up to 0.8-1.0 $\mu \mathrm{m}$ for 
the sample $0.2 \mathrm{Sn}-1000$, as observed from the scanning electron micrographs (Supporting Information, Figure S1). Fibers synthesized at $1200^{\circ} \mathrm{C}$ show a lower number of beads (Figure 2), and a higher amount of Sn clusters inside the fibers; also, the beads present are smaller ( $\leq 200 \mathrm{~nm})$ compared to the samples synthesized at $1000^{\circ} \mathrm{C}$.

During pyrolysis and above $600{ }^{\circ} \mathrm{C}$, metallic tin melts ${ }^{36}$ and the liquid tin forms droplets due to surface tension. ${ }^{36}$ This diffusion limited process takes place mainly during the holding time at $1000-1200{ }^{\circ} \mathrm{C}$. Thereby, the process for tin droplet formation depends on the diffusion kinetics of tin in the formed SiOC. The lower diffusion kinetics of metallic tin in the denser structure of SiOC synthesized at high temperature, restricts the formation of droplets with large sizes.

The chemical composition was characterized by EDX, confirming the presence of mainly SiOC (Table 1). The tin content measured by EDX is not equal to the initially added amount and presents a high standard deviation due to the segregation of $\mathrm{Sn}$ as beads. The tin content, determined with ICP-AES (Table 1), varied in the range of 6-24 mass\% and is not statistically different for samples pyrolyzed at different temperatures. Based on the EDX and ICP-AES results, an estimate of the molar ratio Sn/Si was calculated (Table 1). The values confirm that the molar ratio remains unchanged compared to the initial state, meaning that although Sn droplets are formed the initial tin content is maintained. From the EDX results, an estimate of the SiOC composition ( $\mathrm{C}_{\text {free }}$ and the Si-O-C domains) can be obtained. The molar amount of $\mathrm{O}$ is for every sample at least 2-times the amount of $\mathrm{Si}$, implying a composition of $\mathrm{SiO}_{2}$ as the most likely compound to be formed. For a more accurate characterization of the Si-O-C domains, results from ${ }^{29} \mathrm{Si}$ MAS NMR are presented later. It can be observed that the $\mathrm{C}_{\text {free }}$ content significantly decreases with increasing the tin content: from 3.5-3.7 mol $C_{\text {free }}$ to $2.0-2.4$ mol $_{\text {free }}$ per $1 \mathrm{~mol}$ of Si for the $0.05 \mathrm{Sn}$ and $0.2 \mathrm{Sn}$ samples, respectively.

The $C_{\text {free }}$ phase in the fibers was characterized by Raman spectroscopy (Figure $3 \mathbf{C}$ ). All fibers present characteristic peaks for partially graphitized carbon, with corresponding D- and G-mode at 1333$1350 \mathrm{~cm}^{-1}$ and $1602-1609 \mathrm{~cm}^{-1}$, respectively, and higher order and combination modes at 2500$3000 \mathrm{~cm}^{-1}$. The D-mode relates to breathing modes of six-atoms rings and is activated when a defect is present. ${ }^{37}$ The G-mode is associated with bond stretching of pairs of $\mathrm{sp}^{2}$-hybridized carbon atoms in rings and chains. ${ }^{38}$ The position of the G-mode $\left(1602-1609 \mathrm{~cm}^{-1}\right)$ correlates to the coexistence of amorphous carbon $\left(1550 \mathrm{~cm}^{-1}\right)$ and $\mathrm{sp}^{2}$-hybridized carbon chains, which for pure graphite is located at $1581 \mathrm{~cm}^{-1}$ (Ref. ${ }^{38}$ ). For further analysis, peak deconvolution was performed by use of three Voigt profile peaks in the range of $500-2000 \mathrm{~cm}^{-1}$ (Supporting Information, Figure S4). The data of the peak position, integral $I_{D} / I_{G}$ ratio, and full-width at half-maximum (FWHM) are presented in Table 2 . Samples treated at $1000^{\circ} \mathrm{C}$ present different spectra according to their tin content. Both the D- and G-mode shift to higher wavelengths when increasing the tin content, indicative of a higher presence of amorphous carbon and trans-polyacetylene (between $1200 \mathrm{~cm}^{-1}$ and $1260 \mathrm{~cm}^{-1}$ ). Also, by increasing 
the tin content, the $I_{D} / I_{G}$ ratio reduces, which for graphite domains smaller than $2 \mathrm{~nm}$ implies that less hexagonal carbon rings (also, defects from the hexagonal carbon rings) are present. ${ }^{38}$ For the samples synthesized at high temperatures, no effect on the carbon structure is observed as a function of the tin content. All samples present similar Raman spectra, which compared to the samples synthesized at lower temperatures, present a sharper G-mode peak and a lower amorphous signal, meaning a higher graphitization degree. The FT-IR spectra of the pyrolyzed samples (Figure 3B) present mainly one peak centered between $994-1033 \mathrm{~cm}^{-1}$, corresponding to the vibration mode of the bond $\mathrm{Si}-\mathrm{O}-\mathrm{Si}$, and one smaller peak at between $801-809 \mathrm{~cm}^{-1}$, corresponding with Si-C. ${ }^{31}$ No bands related to $\mathrm{Sn}-\mathrm{O}-\mathrm{Sn}$ bonds are observed, aligning with the absence of $\mathrm{SnO}_{2}$.

For additional analysis of the crystal structure, XRD patterns of the samples were recorded (Figure 3D). In all samples, broad signals coming from tetragonal $\mathrm{SiO}_{2} \mathrm{P}_{1} 2_{1} 2$ (PDF 04-0379; lattice parameters: $a=0.497 \mathrm{~nm}$ and $c=0.693 \mathrm{~nm}$ ) are detected together with sharp peaks corresponding to tetragonal $\mathrm{Sn}$ I41/amd (PDF 04-0673; lattice parameters: $a=0.583 \mathrm{~nm}$ and c=3.182 nm). By applying the Scherrer equation, the average coherence length of the metallic $\mathrm{Sn}$ in the fibers is about 101-138 nm (Table 2). To understand the effect of Sn and the pyrolysis temperature on the resulting SiOC network, ${ }^{29} \mathrm{Si}$ MAS and ${ }^{13} \mathrm{C}$ MAS NMR were collected (Figure 3E-F). The ${ }^{29} \mathrm{Si}$ MAS NMR spectra indicate that in the synthesized samples, the increase in tin content leads to a decrease in the presence of $\mathrm{SiC}_{x} \mathrm{O}_{4-x}$ tetrahedral units (with $1 \leq x \leq 4$ ); consequently, mainly $\mathrm{SiO}_{4}$-units are obtained. This effect is also observed for higher thermal treatment temperatures. For all samples, the ${ }^{29} \mathrm{Si}$ MAS NMR spectra exhibit an intense peak in the range of $-105 \mathrm{ppm}$ to $-110 \mathrm{ppm}$ which corresponds to $\mathrm{SiO}_{4}$ units. For $0.05 \mathrm{Sn}-1000$, a second peak is observed at $-71 \mathrm{ppm}$, corresponding to $\mathrm{SiO}_{3} \mathrm{C}$ units (Supporting Information, Figure S3E). ${ }^{39}$ The intensity of this peak decreases with increasing the heat treatment temperature and is barely visible for the sample $0.05 \mathrm{Sn}-1200$ in Figure 3E. We did not observe any peaks corresponding to $\mathrm{SiO}_{2} \mathrm{C}_{2}(-34 \mathrm{ppm}), \mathrm{SiOC}_{3}(7 \mathrm{ppm})$, or $\mathrm{SiC}_{4}(-11 \mathrm{ppm})$ in any sample. ${ }^{13} \mathrm{C}$ MAS NMR presents mainly a broad peak around $130 \mathrm{ppm}$ for all samples, which is consistent with sp ${ }^{2}$-hybridized carbon. The broad character of the peak is related to large anisotropic susceptibility effects which are not fully averaged by MAS. ${ }^{39}$ As reported by Widgeon et al. for high- and low- carbon SiOC synthesized at $1100{ }^{\circ} \mathrm{C}$, low-carbon $\mathrm{SiOC}\left(\mathrm{C}_{\text {free }}=5.7\right.$ mass $\%$ ) presents more $\mathrm{SiO}_{4}$ units ( $44 \%$ of the $\mathrm{Si}$ units), while the high-carbon $\mathrm{SiOC}\left(\mathrm{C}_{\text {free }}=41.3\right.$ mass $\%$ ) presented fewer $\mathrm{SiO}_{4}$ units ( $32 \%$ of the $\mathrm{Si}$ units) and a higher amount of $\mathrm{SiC}_{4}$ units (17\% of the $\mathrm{Si}$ units). ${ }^{16}$, 39 The higher amount of $\mathrm{SiO}_{4}$ units (above $70 \%$ ), and the absence of $\mathrm{SiC}_{4}$ units in our system is explained by the reduction of $\mathrm{SnO}$ by $\mathrm{C}$ and $\mathrm{Si}$, leading to an oxidation of $\mathrm{C}$ and $\mathrm{Si}$. The oxidation of carbon to volatile species is supported by the decrease in carbon content when increasing the tin content, as supported by the EDX results (Table 1) while the silicon content remains constant. For comparison, the elemental composition of monoliths without Sn (M- 
SiOC) was added to Table 1, corroborating that the presence of Sn modifies the composition of the $\mathrm{SiOC}$ material.

We can conclude that our SiOC material consists of a cellular network of low order graphitic $\mathrm{sp}^{2}$ hybridized carbon, where nanodomains of mainly $\mathrm{SiO}_{4}$ units are sequestered within cells created by the graphitic sheets, and this SiOC material is engulfing larger domains of metallic Sn.

\subsection{Electrochemical performance}

The fabrication of this hybrid fiber material was motivated by enabling several electrochemical advantages: (i) multiple sites for $\mathrm{Li}^{+}$insertion in both systems $\mathrm{SiOC}$ ( $\mathrm{C}_{\text {free }}+\mathrm{Si}-\mathrm{O}-\mathrm{C}$ nanodomains) and metallic Sn, (ii) benefit from the elastic properties of $\mathrm{SiOC}$ to mitigate the volume changes of $\mathrm{Sn},{ }^{16}$ (iii) interfiber space is beneficial to buffer the large volume expansion of the material, and (iv) high conductivity due to the continuous carbon phase in the SiOC fibers. The fiber mats were tested as freestanding electrodes without the addition of any polymer binder or any type of conductive additives. The electrochemical performance was evaluated in $1 \mathrm{M} \mathrm{LiPF}_{6}$ in $\mathrm{EC} / \mathrm{DMC}$, between 3-0.01 V vs. $\mathrm{Li} / \mathrm{Li}^{+}$. Cyclic voltammograms (CVs) were recorded at $0.1 \mathrm{mV} \cdot \mathrm{s}^{-1}$, and are presented in Figure 4 and Supporting Information, Figure S5. During the first cycle, all samples showed a cathodic peak below $1 \mathrm{~V}$ vs. Li/Li+ from the reductive decomposition of the electrolyte and the formation of a solid electrolyte interphase (SEI). Therefore, initially the system was cycled at low rates $(C / 20)$ to promote SEI formation. The latter is a dynamic process in alloy anodes, breaking and reforming at each cycle due to the high volume changes of the electrode. ${ }^{40}$

During the first cycle of $0.1 \mathrm{Sn}-1000$ sample, further cathodic peaks at $+0.62 \mathrm{~V}$ and $+0.34 \mathrm{~V} \mathrm{vs}$. Li/Li+ are observed, corresponding to $\mathrm{LiSn}$ and $\mathrm{Li}_{22} \mathrm{Sn}_{5}$, respectively, followed by a broad and large peak at lower voltages, related to the $\mathrm{Li}^{+}$insertion in the SiOC matrix. All these peaks are blurred by SEI formation reactions during the first cycle, but become clearer for the continuous cycles. During oxidation, several anodic peaks between $+0.63 \mathrm{~V}$ and $+0.82 \mathrm{~V}$ vs. $\mathrm{Li} / \mathrm{Li}^{+}$are observed. During the first cycle, 4 peaks are identified $\left(+0.64,+0.67,+0.75\right.$, and $+0.82 \mathrm{~V}$ vs. $\left.\mathrm{Li} / \mathrm{Li}^{+}\right)$, while only 3 peaks occur in subsequent cycles $\left(+0.65,+0.75\right.$ and $+0.82 \mathrm{~V}$ vs. $\left.\mathrm{Li}_{/} \mathrm{Li}^{+}\right)$. The numerous peaks indicate that dealloying in Sn occurs via multiple reactions and stages ( $\mathrm{Li}_{7} \mathrm{Sn}_{2}, \mathrm{Li}_{13} \mathrm{Sn}_{5}, \mathrm{Li}_{5} \mathrm{Sn}_{2}, \mathrm{Li}_{7} \mathrm{Sn}_{3}, \mathrm{Li}_{2} \mathrm{Sn}_{5}$, and $\left.\mathrm{LiSn}\right){ }_{1}^{41}$ and not as the reverse path described by the cathodic peaks during $\mathrm{Li}^{+}$insertion. The broad peak observed during the oxidation is related with the $\mathrm{Li}^{+}$extraction of carbon, ${ }^{36}$ and $\mathrm{SiO}_{2}$ nanodomains. Further anodic peaks are only observed during the first cycle at almost $+3 \mathrm{~V} \mathrm{vs}$. $\mathrm{Li}^{\prime} / \mathrm{Li}^{+}$, which could be related to reabsorption of hydrogen formed during the reduction step.

Comparing the first cycle of the samples pyrolyzed at $1000^{\circ} \mathrm{C}$, the amplitude of the anodic peaks (between $+0.63 \mathrm{~V}$ and $+0.82 \mathrm{~V}$ vs. $\mathrm{Li}^{\prime} \mathrm{Li}^{+}$) increases proportionally to the tin content (Supporting Information, Figure S5A-B). The intensity of these peaks in the next cycles decreases proportionally to 
the tin content. At the $5^{\text {th }}$ cycle (Figure 4 C), all CVs present similar shapes, but some differences in peak position and intensity are observed. During lithiation, the first cathodic peak is shifted from $+0.63 \mathrm{~V}$ to $+0.61 \mathrm{~V}$ vs. $\mathrm{Li} / \mathrm{Li}^{+}$, while the intensity of a second peak at $+0.36 \mathrm{~V}$ vs. $\mathrm{Li} / \mathrm{Li}^{+}$decreases when increasing the tin content. During $\mathrm{Li}^{+}$extraction, the peaks located at $+0.63 \mathrm{~V},+0.73 \mathrm{~V}$, and $+0.80 \mathrm{~V} \mathrm{vs}$. Li/ $\mathrm{Li}^{+}$shift to higher voltages for the sample $0.05 \mathrm{Sn}-1000$. The increase of the voltage difference, for reduction and oxidation, together with the decrease in intensity of the peaks, indicate an increasing overpotential due to electron transport limitations. As observed for hybrid Sn/C particles, during the first cycles a high capacity fading is observed related to partly particle pulverization of the Sn particles. ${ }^{36}$ The large size of the Sn particles in our system and the segregation of some of them due to Sn melting during pyrolysis contribute to a large capacity fading in the first cycles.

Compared to samples synthesized at higher temperatures (Figure 4B,D), two main differences are observed. For the samples synthesized at $1200^{\circ} \mathrm{C}$, the intensity of the peaks related to tin redoxreaction are less intense, but are observed at similar voltages, and the CVs present a higher area, which indicates a generally higher capacity. Also, after the $5^{\text {th }}$ cycle, these samples present similar shapes (Figure 4D). There exist mainly two differences between the materials synthesized at $1000^{\circ} \mathrm{C}$ and $1200^{\circ} \mathrm{C}$ : the degree of carbon ordering, and the particle size of the Sn beads. An increase in the conductivity of the $\mathrm{SiOC}$ matrix leads to a higher $\mathrm{Li}^{+}$insertion into the $\mathrm{Si}-\mathrm{O}-\mathrm{C}$ tetrahedra units and a more homogenous current and voltage distribution throughout the electrode during charging. The effect of the pyrolysis temperature in the conductivity is corroborated by the sheet resistance values, $0.71-0.98 \Omega \cdot \mathrm{cm}$ and $0.28-0.32 \Omega \cdot \mathrm{cm}$ for samples synthesized at $1000^{\circ} \mathrm{C}$ and $1200{ }^{\circ} \mathrm{C}$, respectively (Table 3). The decrease in the intensity of the Sn alloy peaks, is related to the lower formation of longrange ordered structures. ${ }^{41}$ For the samples synthesized at $1000^{\circ} \mathrm{C}$, lithium intercalates in Sn in two different mechanism, the well dispersed nanoparticles in the SiOC fibers, and the large segregated Sn sub-micrometer-sized particles outside the fibers. For the samples synthetized at $1200^{\circ} \mathrm{C}, \mathrm{Sn}$ is mainly present as nanoparticles well dispersed inside the SiOC fibers, which explains the lower but more stable intensity of the $\mathrm{Sn}$ alloy peaks.

For a quantitative characterization of $\mathrm{Li}^{+}$insertion in the hybrid material, the capacity during lithiation and delithiation was characterized by galvanostatic cycling between 3-0.01 V vs. Li/Li+. The voltage profile for the first cycle $\left(35 \mathrm{~mA} \cdot \mathrm{g}^{-1}, 0.05 \mathrm{C}\right)$ is presented in Figure 5A-B and key data are reported in Table 3. During the discharging step, we see a rapid decrease in the voltage before achieving $+1 \mathrm{~V}$ vs. $\mathrm{Li} / \mathrm{Li}^{+}$, at which reduction reactions start to take place, leading later to a voltage plateau at $0.5-0.01 \mathrm{~V}$ vs. Li/Li+. The initial insertion capacity was similar for all samples, namely $1075-1178 \mathrm{mAh} \cdot \mathrm{g}^{-1}$. The SEI formation and the irreversible $\mathrm{Li}^{+}$insertion into the nanocomponents ${ }^{42}$ lead to a low Coulombic efficiency of 0.75 and 0.82 for the samples treated at $1000{ }^{\circ} \mathrm{C}$ and $1200{ }^{\circ} \mathrm{C}$, respectively. This could be influenced by the carbon ordering, since ordered carbons are characterized by a higher initial charge 
efficiency. ${ }^{43}$ It was observed that the Coulombic efficiency for the first cycle increases with increasing the tin content and the pyrolysis temperature. However the coulombic efficiency stabilizes faster achieving values close to 1 , for low tin content, and also the capacity fading is lower for low tin content, which is related to partly particle pulverization of the large Sn particles. ${ }^{36}$ In the case of the samples treated at high temperatures, the initial lithiation/delithiation capacity is proportional to the tin content, while for the sample at $1000^{\circ} \mathrm{C}$, the highest capacity was obtained for the sample $0.1 \mathrm{Sn}$ 1000. A fast decay is observed in the next 5 cycles, but with a decrease of the irreversible capacity. After 5 cycles, the samples synthesized at high temperatures, maintain a higher delithiation capacity between $\left(842-791 \mathrm{mAh} \cdot \mathrm{g}^{-1}\right)$.

At higher rates $\left(140 \mathrm{~mA} \cdot \mathrm{g}^{-1}\right)$, the samples treated at $1200{ }^{\circ} \mathrm{C}$ maintain similar capacity values around $550 \mathrm{mAh} \cdot \mathrm{g}^{-1}$. For samples synthesized at lower temperatures, larger differences are observed. The sample $0.1 \mathrm{Sn}-1000$ presented a higher capacity $\left(525 \mathrm{mAh} \cdot \mathrm{g}^{-1}\right)$ while the other samples retained 380$430 \mathrm{mAh} \cdot \mathrm{g}^{-1}$. At higher rates, the capacity values for all samples tends to be similar; only the sample $0.05 \mathrm{Sn}-1000$ presented consistently a lower capacity. For the samples treated at low temperature, after the fast decay in the first cycles, the sample which presents the more stable rate handling performance was $0.2 \mathrm{Sn}-1000$, which after 100 cycles also maintained the highest capacity $277 \mathrm{mAh} \cdot \mathrm{g}$ ${ }^{1}$. Samples with a lower amount of Sn presented a higher capacity fading. For the samples synthesized at higher temperatures, higher capacity retention is observed, maintaining between $400-509 \mathrm{mAh} \cdot \mathrm{g}^{-1}$ after 100 cycles. In this case, the samples present a more similar rate handling behavior and stability. To explain the effect of the heat treatment and tin content on the observed electrochemical performance, we must consider the theoretical $\mathrm{Li}^{+}$insertion capacity of the present phases and how the Li-storage takes place in silicon oxycarbides. The theoretical capacity of graphite, $\mathrm{SiO}_{2}$, and $\mathrm{Sn}$, correspond to 372,1784 , and $993 \mathrm{mAh} \cdot \mathrm{g}^{-1}$, respectively. ${ }^{5}, 40$ Therefore, our samples have a maximum theoretical capacity o $1150-1300 \mathrm{mAh} \cdot \mathrm{g}^{-1}$ when applying a simplified model for the SiOC composition (Supporting Information, Table S2). There is still an open debate in the literature on the active sites for the Li storage in silicon oxycarbides; however, there are some features which are often reported: SiC is not electrochemically active and both $\mathrm{Si}-\mathrm{O}-\mathrm{C}$ nanodomains and the $\mathrm{C}_{\text {free }}$ phase contribute to the $\mathrm{Li}^{+}$ insertion. ${ }^{8}$ The proposed sites for reversible lithium storage in SiOC include the Si-O-C tetrahedra units, micropores, and the free carbon phase. ${ }^{8}$ Without free carbon, lithium storage in the Si-O-C domains cannot occur since a certain amount of carbon is needed to ensure sufficient electronic conductivity. ${ }^{44}$ Additionally, the electronic conductivity of the free carbon phase can homogenize the voltage and current distribution throughout the electrode in order to avoid local electrode degradation spots. ${ }^{45}$ While in some aspects, the presence of $C_{\text {free }}$ is beneficial, there are some aspects at which it is not. $C_{\text {free }}$ phase facilitates the formation of $\mathrm{Li}-\mathrm{O}$ bonds, leading to irreversible lithium uptake under the presence 
of carbon in the SiOC. ${ }^{16,44}$ Also, while a higher graphitization degree of carbon is beneficial for a higher conductivity, higher ordered carbons can host less $\mathrm{Li}^{+}$than less ordered. ${ }^{13}$

In our system, all three phases contribute to the overall $\mathrm{Li}^{+}$insertion/extraction. A graphical representation of the phases is presented in the Supporting Information, Figure S6A. A higher tin content yields a higher initial reversible capacity; however, this is accompanied by a fast capacity fading after the first 5 cycles. Also, this increase in the reversible capacity with the tin content was only observed for the samples synthesized at $1200^{\circ} \mathrm{C}$, with a more conductive $C_{\text {free }}$ (Table 3). The $C_{\text {free }}$ phase presents the lowest volumetric expansion $\left(\approx 10 \%\right.$; Ref. $\left.{ }^{5}\right)$ and demonstrates to have a crucial role in the stability and rate handling of the system. Therefore, we found that a high and stable performance depends on the electrical conductivity and the volumetric expansion during $\mathrm{Li}^{+}$insertion/extraction. During $\mathrm{Li}^{+}$insertion/extraction, the large particle size and the high volumetric expansion of the metallic tin $(\approx 260 \%)^{40}$ may pulverize the particles; therefore, the contribution of the metallic tin to the electrochemical performance decreases during the first cycles. It has been already reported that for Crich $\mathrm{SiOC}$, the carbon phase accommodate the high volume expansion during alloying with $\mathrm{Li}^{+}$, preventing electrode failure. ${ }^{16}$ Cracking and pulverization of the active particles and the surrounding matrix lead to the disconnection of some alloy particles from the conductive carbon or current collector, and this isolation of the particles leads to incomplete delithiation reaction. ${ }^{40}$ In our case, the fiber morphology is maintained (Supporting Information, Figure S6B-C) and the electrodes continue being free-standing after 100 cycles; possibly, the interfiber space helps to compensate the volume expansion. However, the Sn beads have disappeared after 100 cycles, and some particles nonconnected to the fiber network are observed, which could be relate to the pulverization of the Sn beads. To corroborate this failure mechanism during cyclic test, post-mortem TEM and EDX analysis was performed (Supporting Information, Figure S6-7). The TEM images are characterized by two different regions: a dense $\mathrm{SiOC}$ material and less dense region with the presence of Sn nanoparticles. The post-mortem SiOC material presents more holes compared to pristine SiOC, and some Sn nanoparticles were observed dispersed outside of the SiOC particles. According to the elemental analysis, the less dense region consists mainly of $C, O, F$, and $P$ engulfing the $S n$ nanoparticles, as observed from the TEM images. As can be seen, some of the $\mathrm{Sn}$ nanoparticles are seemingly separated from the $\mathrm{SiOC}$ matrix during cyclic testing.

The electrochemical performance of the samples 0.05 Sn-1200 and 0.2 Sn-1200 was compared with literature and Table $\mathbf{4}$ includes data for the pyrolysis temperature and tin content. The electrochemical data presented in Table $\mathbf{4}$ correspond mostly to high-carbon SiOC materials for a fair comparison, since low-carbon SiOC are well known for presenting a lower electrochemical performance. ${ }^{8}$ Our materials present a higher first cycle reversible capacity. This is attributed to several factors: the complete electrode mass contributes to the lithium insertion (no polymer-binder or additional conductive 
additive), the presence of metallic tin, and the high conductivity of the continuous fiber network. The improved conductivity is observed by the higher capacity retention at higher rates, despite the higher mass loading of our electrodes. Also, compared to literature, the effect of the pyrolysis in the electrochemical performance of SiOC systems differs. It has been reported that a lower pyrolysis temperature $\left(900^{\circ} \mathrm{C}\right)$, leads to higher capacity values. ${ }^{13}$ For high-carbon $\mathrm{SiOC}$, a higher pyrolysis temperature leads to an increase in $\mathrm{SiC}_{4}$ units, which are not electrochemically active, ${ }^{8}$ dropping the capacity of the system. In our systems, the presence of $\mathrm{Sn}$, promoted the increase of $\mathrm{SiO}_{4}$ units and avoided the formation of $\mathrm{C}$ containing units, therefore a heat treatment at higher temperatures, helped to obtain a more conductive material, leading to higher capacity values and a higher stability.

\subsection{Comparison to Sn-free SiOC}

The chemical characterization results in Section $\mathbf{3 . 2}$ have demonstrated that Sn modifies the composition of SiOC. To corroborate the effect of $\mathrm{Sn}$ in the electrochemical performance, SiOC monoliths with (M-0.05 Sn) and without Sn (M-SiOC) were prepared and tested. The monoliths were tested as polymer-bound electrodes by admixing carbon black (C65) as conductive additive. The results are presented in the Supporting Information Figure $\mathbf{S 8 .}$

Comparing the polymer-bound electrodes and the fiber electrodes, a drastic difference is observed in the rate handling performance which relates to the much higher sheet resistivity of the polymer-bound electrodes compared to the fiber mat electrodes (Supporting Information, Table S3). Comparing the

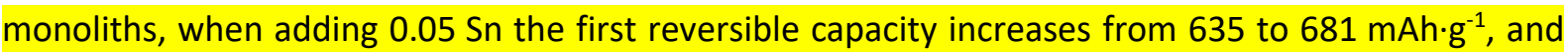
from 677 to $741 \mathrm{mAh} \cdot \mathrm{g}^{-1}$ for the samples synthesized at 1000 and $1200{ }^{\circ} \mathrm{C}$, respectively. The monoliths produced at higher temperature, present a more stable performance, but in all cases lower than the fiber mat electrodes. The lower stability of the polymer-bound electrodes is related to the higher particle size $(5-10 \mu \mathrm{m})$ and lower conductivity of the non-continuous network, compared to the fiber mats.

\section{Conclusions}

We synthesized continuous SiOC fiber mat electrodes free of polymer binder and conductive additives, for use anode material for Li-ion batteries. The synthesis is based on the electrospinning of a low-cost silicone resin, using tin acetate as a polymer crosslinker. We found that adding a low amount of tin acetate $(0.05 \mathrm{~mol} \mathrm{Sn}$ per $1 \mathrm{~mol} \mathrm{Si})$ is necessary for a complete crosslinking, maintaining the fiber shape during thermal treatment. After crosslinking and during pyrolysis between $1000-1200{ }^{\circ} \mathrm{C}$, a hybrid material is formed, containing a carbon-rich $\mathrm{SiOC}$ matrix and metallic tin clusters. During pyrolysis, SnO is reduced to metallic tin, causing the oxidation of carbon and silicon, promoting a higher presence of $\mathrm{SiO}_{4}$ units in the $\mathrm{SiOC}$ matrix and reducing the carbon content. This effect depends on the amount of 
added tin, with low amounts of tin $(0.05 \mathrm{~mol}$ Sn per $1 \mathrm{~mol} \mathrm{Si})$ avoiding the formation of electrochemically inactive $\mathrm{SiC}_{4}$ units. Higher tin amounts decrease the conductivity of the fibers by removing the conductive carbon phase. Since the presence of $\mathrm{Sn}$ promotes the existence of $\mathrm{SiO}_{4}$ units, pyrolysis can be performed at higher temperatures $\left(1200^{\circ} \mathrm{C}\right)$ without forming inactive $\mathrm{SiC}_{4}$ and benefiting of the more graphitic and conductive $C_{\text {free }}$ phase. It was also found that pyrolysis at $1000^{\circ} \mathrm{C}$ and high amounts of tin (0.1-0.2 mol per $1 \mathrm{~mol} \mathrm{Si}$ ) lead to a higher segregation of tin into beads outside the fiber shape. This single precursor approach has several advantages for producing continuous $\mathrm{Sn} / \mathrm{SiOC}$ composite fibers: (i) by an in-situ synthesis a uniform distribution of Sn particles in the SiOC matrix is obtained, (ii) the continuous matrix ensures the conductivity of the system and helps to constrain the volume expansion, and (iii) the material properties can be tailored according to the desired electrochemical properties.

The hybrid materials synthesized at $1200^{\circ} \mathrm{C}$, present very high initial reversible capacities (840$994 \mathrm{mAh} \cdot \mathrm{g}^{-1}$ ) at $35 \mathrm{~mA} \cdot \mathrm{g}^{-1}$, and retain $280-310 \mathrm{mAh} \cdot \mathrm{g}^{-1}$ at $350 \mathrm{~mA} \cdot \mathrm{g}^{-1}$ specific current. After 100 cycles at $70 \mathrm{~mA} \cdot \mathrm{g}^{-1}$, the hybrid fibers maintained between $400-509 \mathrm{mAh} \cdot \mathrm{g}^{-1}$. This capacity values, are related to tin alloying and $\mathrm{Li}^{+}$insertion reactions into the $\mathrm{Si}-\mathrm{O}-\mathrm{C}$ tetrahedra units, the presence of micropores, and the $C_{\text {free }}$ phase. Without tin segregation outside the fibers and uniform distribution of tin in the SiOC fiber matrix (pyrolysis $1200^{\circ} \mathrm{C}$ ), a higher amount of $\mathrm{Sn}$ is beneficial for a higher reversible capacity in the first cycles. However, the higher volumetric expansion during lithiation of metallic tin possibly explains a higher capacity fading and a lower performance stability. At high rates, all systems have similar capacity values, meaning that tin is not significantly contributing to the $\mathrm{Li}^{+}$insertion capacity, but mainly the $\mathrm{C}$-rich SiOC. The $\mathrm{C}_{\text {free }}$ phase has a significative influence in the stability of the system. The $C_{\text {free }}$ phase is present mainly as $\mathrm{sp}^{2}$-hybridized layers, and according to the electrochemical performance of the different samples, it was found that a higher amount of carbon, and a higher graphitization degree is crucial for a higher conductivity and a stable electrochemical performance. Adding low amounts of $\mathrm{Sn}$ is beneficial not just for the crosslinking of the polymer precursor, but also to decrease the presence of $\mathrm{SiC}_{4}$ electrochemically inactive species in the $\mathrm{SiOC}$, and form metallic tin clusters which contribute to a higher $\mathrm{Li}^{+}$insertion in the first cycles.

\section{Acknowledgements}

We acknowledge funding from the German Federal Ministry for Economic Affairs and Energy (BMWi) in support of the HyBaCap project (award number 03ET6113C). The authors thank Prof. Eduard Arzt for his continuing support, Robert Drumm for his support for TGA-MS measurements, and Andrea Jung for her support with ICPAES measurements (all at INM). We also thank Dr. Soumyadip Choudhury, Nicolas Jäckel, Juhan Lee, and Dr. Eunho Lim for discussions and brainstorming (all at INM). 


\section{References}

1. B. Dunn, H. Kamath and J.-M. Tarascon, Science, 2011, 334, 928-935.

2. H. Li, Z. Wang, L. Chen and X. Huang, Advanced Materials, 2009, 21, 4593-4607.

3. B. Scrosati and J. Garche, Journal of Power Sources, 2010, 195, 2419-2430.

4. $\quad$ B. Scrosati, J. Hassoun and Y.-K. Sun, Energy \& Environmental Science, 2011, 4, 3287-3295.

5. S. Goriparti, E. Miele, F. De Angelis, E. Di Fabrizio, R. Proietti Zaccaria and C. Capiglia, Journal of Power Sources, 2014, 257, 421-443.

6. R. Dash and S. Pannala, Scientific Reports, 2016, 6, 27449.

7. A. M. Wilson and J. R. Dahn, Journal of The Electrochemical Society, 1995, 142, 326-332.

8. V. S. Pradeep, M. Graczyk-Zajac, R. Riedel and G. D. Soraru, Electrochimica Acta, 2014, 119, 7885.

9. P. Colombo, G. Mera, R. Riedel and G. D. Sorarù, Journal of the American Ceramic Society, 2010, 93, 1805-1837.

10. G. Mera, A. Navrotsky, S. Sen, H.-J. Kleebe and R. Riedel, Journal of Materials Chemistry A, 2013, 1, 3826-3836.

11. M. Graczyk-Zajac, L. Toma, C. Fasel and R. Riedel, Solid State lonics, 2012, 225, 522-526.

12. P. Dibandjo, M. Graczyk-Zajac, R. Riedel, V. S. Pradeep and G. D. Soraru, Journal of the European Ceramic Society, 2012, 32, 2495-2503.

13. J. Kaspar, M. Graczyk-Zajac and R. Riedel, Journal of Power Sources, 2013, 244, 450-455.

14. J. Kaspar, M. Graczyk-Zajac, S. Lauterbach, H.-J. Kleebe and R. Riedel, Journal of Power Sources, 2014, 269, 164-172.

15. M. Zhu, J. Yang, Z. Yu, H. Chen and F. Pan, Journal of Materials Chemistry A, 2017, 5, 70267034.

16. J. Kaspar, C. Terzioglu, E. Ionescu, M. Graczyk-Zajac, S. Hapis, H.-J. Kleebe and R. Riedel, Advanced Functional Materials, 2014, 24, 4097-4104.

17. A. Tolosa, B. Krüner, N. Jäckel, M. Aslan, C. Vakifahmetoglu and V. Presser, Journal of Power Sources, 2016, 313, 178-188.

18. A. Tolosa, B. Krüner, S. Fleischmann, N. Jäckel, M. Zeiger, M. Aslan, I. Grobelsek and V. Presser, Journal of Materials Chemistry A, 2016, 4, 16003-16016.

19. S. Li, C. Chen, K. Fu, L. Xue, C. Zhao, S. Zhang, Y. Hu, L. Zhou and X. Zhang, Solid State lonics, 2014, 254, 17-26.

20. Y. Li, B. Guo, L. Ji, Z. Lin, G. Xu, Y. Liang, S. Zhang, O. Toprakci, Y. Hu, M. Alcoutlabi and X. Zhang, Carbon, 2013, 51, 185-194.

21. Y. Li, Y. Hu, Y. Lu, S. Zhang, G. Xu, K. Fu, S. Li, C. Chen, L. Zhou, X. Xia and X. Zhang, Journal of Power Sources, 2014, 254, 33-38.

22. X. Xia, X. Wang, H. Zhou, X. Niu, L. Xue, X. Zhang and Q. Wei, Electrochimica Acta, 2014, 121, 345-351.

23. M. Dirican, O. Yildiz, Y. Lu, X. Fang, H. Jiang, H. Kizil and X. Zhang, Electrochimica Acta, 2015, 169, 52-60.

24. G. Kickelbick, in Hybrid Materials, Wiley-VCH Verlag GmbH \& Co. KGaA, 2007, DOI: 10.1002/9783527610495.ch1, pp. 1-48.

25. A. Guo, M. Roso, M. Modesti, J. Liu and P. Colombo, Journal of Applied Polymer Science, 2014, $131,39836$.

26. J. S. Atchison, M. Zeiger, A. Tolosa, L. M. Funke, N. Jäckel and V. Presser, RSC Advances, 2015, 5, 35683-35692.

27. H. J. T. Ellingham, J Soc Chem Ind, 1944, 63, 125-133.

28. C. A. Schneider, W. S. Rasband and K. W. Eliceiri, Nature Methods, 2012, 9, 671-675.

29. D. Weingarth, M. Zeiger, N. Jäckel, M. Aslan, G. Feng and V. Presser, Advanced Energy Materials, 2014, 4, 1400316.

30. G. Socrates, Infrared and Raman Characteristic Group Frequencies: Tables and Charts, Wiley, 2004. 
31. T. Oh and C. Choi, Journal of the Korean Physical Society, 2010, 56(4), 1150-1155.

32. D. L. Pavia, G. M. Lampman, G. S. Kriz and J. A. Vyvyan, Introduction to Spectroscopy, Cengage Learning, 2008.

33. V. Belot, R. J. P. Corriu, D. Leclercq, P. H. Mutin and A. Vioux, Journal of Polymer Science Part A: Polymer Chemistry, 1992, 30, 613-623.

34. J. Cordelair and P. Greil, Journal of the European Ceramic Society, 2000, 20, 1947-1957.

35. E. lonescu, C. Terzioglu, C. Linck, J. Kaspar, A. Navrotsky and R. Riedel, Journal of the American Ceramic Society, 2013, 96, 1899-1903.

36. W.-M. Zhang, J.-S. Hu, Y.-G. Guo, S.-F. Zheng, L.-S. Zhong, W.-G. Song and L.-J. Wan, Advanced Materials, 2008, 20, 1160-1165.

37. A. C. Ferrari and D. M. Basko, Nature Nanotechnology, 2013, 8, 235-246.

38. A. C. Ferrari, Solid State Communications, 2007, 143, 47-57.

39. S. J. Widgeon, S. Sen, G. Mera, E. Ionescu, R. Riedel and A. Navrotsky, Chemistry of Materials, 2010, 22, 6221-6228.

40. W.-J. Zhang, Journal of Power Sources, 2011, 196, 13-24.

41. M. Winter and J. O. Besenhard, Electrochimica Acta, 1999, 45, 31-50.

42. Y.-S. Hu, R. Demir-Cakan, M.-M. Titirici, J.-O. Müller, R. Schlögl, M. Antonietti and J. Maier, Angewandte Chemie International Edition, 2008, 47, 1645-1649.

43. Y. Nishi, The Electrochemical Society Interface, 2016, 25, 71-74.

44. M. Graczyk-Zajac, L. Reinold, J. Kaspar, P. Sasikumar, G.-D. Soraru and R. Riedel, Nanomaterials, 2015, 5, 233.

45. M. Widmaier, N. Jäckel, M. Zeiger, M. Abuzarli, C. Engel, L. Bommer and V. Presser, Electrochimica Acta, 2017, 247, 1006-1018. 
Tables

Table 1: Results from the EDX and ICP-AES of the fiber mats ( $\mathrm{Sn} / \mathrm{SiOC}$ ) and monoliths (SiOC). Calculated composition of SiOC based on the EDX results, and calculated values for Sn/Si molar ratio based on EDX and ICP-AES results.

\begin{tabular}{cccccccc}
\hline \multirow{2}{*}{ Sample } & SiOC composition & \multirow{S}{*}{$\begin{array}{c}\mathrm{Sn} / \mathrm{Si} \\
\text { molar ratio }\end{array}$} & $\mathbf{C}$ & $\mathbf{0}$ & $\mathbf{S i}$ & $\mathrm{Sn}$ & \multirow{2}{*}{$\begin{array}{c}\text { ICP-AES } \\
\text { Sn mass\% }\end{array}$} \\
\cline { 4 - 7 } $\mathrm{M}-\mathrm{SiOC}-1000$ & $4.6 \mathrm{C}_{\text {free }}+\mathrm{SiO}_{2}$ & - & $47 \pm 2$ & $28 \pm 1$ & $24 \pm 3$ & - & - \\
\hline $0.05 \mathrm{Sn}-1000$ & $3.5 \mathrm{C}_{\text {free }}+\mathrm{SiO}_{2}$ & 0.06 & $36 \pm 2$ & $28 \pm 2$ & $24 \pm 3$ & $11 \pm 4$ & $6.2 \pm 0.1$ \\
\hline $0.1 \mathrm{Sn}-1000$ & $3.0 \mathrm{C}_{\text {free }}+\mathrm{SiO}_{2}$ & 0.10 & $32 \pm 1$ & $33 \pm 2$ & $25 \pm 2$ & $9 \pm 2$ & $10.4 \pm 0.2$ \\
\hline $0.2 \mathrm{Sn}-1000$ & $2.4 \mathrm{C}_{\text {free }}+\mathrm{SiO}_{2}$ & 0.24 & $24 \pm 2$ & $38 \pm 2$ & $24 \pm 3$ & $14 \pm 6$ & $22.1 \pm 0.1$ \\
\hline $\mathrm{M}-\mathrm{SiOC}-1200$ & $4.1 \mathrm{C}_{\text {free }}+\mathrm{SiO}_{1.35} \mathrm{C}_{0.32}$ & - & $52 \pm 8$ & $21 \pm 5$ & $26 \pm 2$ & - & - \\
\hline $0.05 \mathrm{Sn}-1200$ & $3.7 \mathrm{C}_{\text {free }}+\mathrm{SiO}_{2}$ & 0.06 & $41 \pm 1$ & $32 \pm 2$ & $26 \pm 2$ & $1 \pm 1$ & $6.4 \pm 0.1$ \\
\hline $0.1 \mathrm{Sn}-1200$ & $3.2 \mathrm{C}_{\text {free }}+\mathrm{SiO}_{2}$ & 0.10 & $36 \pm 1$ & $32 \pm 1$ & $26 \pm 1$ & $5 \pm 1$ & $10.7 \pm 0.1$ \\
\hline $0.2 \mathrm{Sn}-1200$ & $2.0 \mathrm{C}_{\text {free }}+\mathrm{SiO}_{2}$ & 0.22 & $23 \pm 3$ & $37 \pm 4$ & $27 \pm 5$ & $13 \pm 10$ & $21.9 \pm 0.1$ \\
\hline
\end{tabular}

Table 2: Results for average coherence length of tetragonal Sn from XRD analysis, and results from the peak deconvolution of Raman spectra.

\begin{tabular}{cccccccc}
\hline \multirow{2}{*}{ Sample } & $\begin{array}{c}\text { Coherence } \\
\text { length }(\mathbf{n m})\end{array}$ & $\begin{array}{c}\text { D-mode } \\
\left(\mathbf{c m}^{-1}\right)\end{array}$ & $\begin{array}{c}\text { G-mode } \\
\left(\mathbf{c m}^{-1}\right)\end{array}$ & $\mathbf{I}_{\mathbf{D}} / \mathbf{I}_{\mathbf{G}}$ & \multicolumn{2}{c}{ FWHM $\left(\mathbf{c m}^{-1}\right)$} \\
\hline $0.05 \mathrm{Sn}-1000$ & 132 & 1335 & 1602 & 2.01 & $200.0 \pm 0.6$ & $71.4 \pm 1.0$ \\
\hline $0.1 \mathrm{Sn}-1000$ & 105 & 1340 & 1603 & 2.03 & $206.6 \pm 0.7$ & $72.1 \pm 0.8$ \\
\hline $0.2 \mathrm{Sn}-1000$ & 101 & 1350 & 1607 & 1.73 & $203.1 \pm 1.0$ & $71.9 \pm 2.0$ \\
\hline $0.05 \mathrm{Sn}-1200$ & 122 & 1335 & 1603 & 1.58 & $180.9 \pm 0.5$ & $65.4 \pm 1.0$ \\
\hline $0.1 \mathrm{Sn}-1200$ & 102 & 1333 & 1604 & 1.67 & $178.3 \pm 0.5$ & $63.2 \pm 0.8$ \\
\hline $0.2 \mathrm{Sn}-1200$ & 138 & 1339 & 1609 & 1.56 & $178.1 \pm 0.8$ & $65.8 \pm 1.4$ \\
\hline
\end{tabular}

Table 3: Results from electrochemical testing by galvanostatic cycling, and sheet resistance of the electrodes.

\begin{tabular}{|c|c|c|c|c|c|c|}
\hline \multirow{2}{*}{ Sample } & \multicolumn{4}{|c|}{ Capacity at $35 \mathrm{~mA} \cdot \mathrm{g}^{-1}\left(\mathrm{mAh} \cdot \mathrm{g}^{-1}\right)$} & \multirow{2}{*}{$\begin{array}{c}\text { Reversible } \\
\text { - capacity after } 100 \\
\text { cycles }\left(\mathrm{mAh} \cdot \mathrm{g}^{-1}\right)\end{array}$} & \multirow{2}{*}{$\begin{array}{c}\text { Sheet } \\
\text { resistance } \\
(\Omega \cdot \mathrm{cm}) \\
\end{array}$} \\
\hline & $1^{\text {st }}$ lithiatic & ion $1^{\text {st }}$ delithiation $5^{\text {th }}$ & ${ }^{\mathrm{h}}$ lithiation $5^{\mathrm{t}}$ & ${ }^{\text {th }}$ delithiation & & \\
\hline $0.05 \mathrm{Sn}-1000$ & 1097 & 789 & 725 & 607 & 221 & $0.71 \pm 0.10$ \\
\hline $0.1 \mathrm{Sn}-1000$ & 1143 & 881 & 750 & 744 & 281 & $0.90 \pm 0.15$ \\
\hline $0.2 \mathrm{Sn}-1000$ & 1093 & 821 & 632 & 613 & 277 & $0.98 \pm 0.13$ \\
\hline 0.05 Sn-1200 & 1075 & 840 & 804 & 801 & 509 & $0.28 \pm 0.05$ \\
\hline $0.1 \mathrm{Sn}-1200$ & 1145 & 939 & 854 & 842 & 457 & $0.31 \pm 0.05$ \\
\hline $0.2 \mathrm{Sn}-1200$ & 1178 & 994 & 806 & 791 & 400 & $0.32 \pm 0.03$ \\
\hline
\end{tabular}


Table 4: Comparison among different $\mathrm{SiOC}$ and $\mathrm{Sn} / \mathrm{SiOC}$ electrodes for battery-like systems. For electrode preparation, conductive additives (CA) and a polyvinylidene fluoride (PVdF) are added during deposition by doctor blade (DBD) technique to the current collector. The mass loading of the electrodes is reported here for a fair comparison. The capacity values $\left(\mathrm{mAh} \cdot \mathrm{g}^{-1}\right)$ are normalized to total electrode mass and to the active mass (am).

\begin{tabular}{|c|c|c|c|c|}
\hline Sample & Electrode & $\begin{array}{c}1^{\text {st }} \text { cycle } C_{\text {rev }} \\
\left(\mathrm{mAh} \cdot \mathrm{g}^{-1}\right)\end{array}$ & $\begin{array}{l}\text { Capacity at } \\
\text { high rate } \\
\text { (V vs. Li/Li+) }\end{array}$ & Reference \\
\hline $\begin{array}{l}\text { Sn (6 mass\%) } \\
/ \text { SiOC-1200 } \mathrm{C} \\
\text { fibers }\end{array}$ & $\begin{array}{l}\text { Free standing } \\
\left(8.6 \mathrm{mg} \cdot \mathrm{cm}^{-2}\right)\end{array}$ & $\begin{array}{c}840 \\
\text { (am: 840) }\end{array}$ & $\begin{array}{l}303 \text { (am: } 303 \text { ) } \\
\text { at } 350 \mathrm{~mA} \cdot \mathrm{g}^{-1}\end{array}$ & $\begin{array}{c}\text { This work; } 1 \mathrm{M} \\
\text { LiPF }_{6} \\
\text { in EC/DM }\end{array}$ \\
\hline $\begin{array}{l}\text { Sn (22 mass\%) } \\
/ \text { SiOC-1200 } \\
\text { fibers }\end{array}$ & $\begin{array}{l}\text { Free standing } \\
\left(8.3 \mathrm{mg} \cdot \mathrm{cm}^{-2}\right)\end{array}$ & $\begin{array}{c}994 \\
\text { (am: 994) }\end{array}$ & $\begin{array}{l}268(\mathrm{am}: 268) \\
\text { at } 350 \mathrm{~mA} \cdot \mathrm{g}^{-1}\end{array}$ & $\begin{array}{c}\text { This work; } 1 \mathrm{M} \\
\text { LiPF }_{6} \\
\text { in EC/DM }\end{array}$ \\
\hline $\begin{array}{l}\text { SiOC- } 1100^{\circ} \mathrm{C} \\
\text { microsized } \\
\text { particles }\end{array}$ & $\begin{array}{c}\text { DBD with CA } \\
\text { and PVdF } \\
\left(3.3 \mathrm{mg} \cdot \mathrm{cm}^{-2}\right)\end{array}$ & $\begin{array}{c}452 \\
\text { (am: 532) }\end{array}$ & $\begin{array}{l}274 \text { (am: } 323 \text { ) } \\
\text { at } 372 \mathrm{~mA} \cdot \mathrm{g}^{-1}\end{array}$ & $\begin{array}{c}\text { Ref. }{ }^{13} ; \\
1 \mathrm{M} \mathrm{LiPF}_{6} \text { in } \\
\text { EC/DMC }\end{array}$ \\
\hline $\begin{array}{l}\text { Sn (25 mass\%) } \\
/ \text { SiOC-1000 }{ }^{\circ} \mathrm{C} \\
\text { microsized } \\
\text { particles }\end{array}$ & $\begin{array}{l}\text { DBD with CA } \\
\text { and PVdF } \\
\left(4.5 \mathrm{mg} \cdot \mathrm{cm}^{-2}\right)\end{array}$ & $\begin{array}{c}553 \\
\text { (am: 651) }\end{array}$ & $\begin{array}{l}230(\mathrm{am}: 270) \\
\text { at } 372 \mathrm{~mA} \cdot \mathrm{g}^{-1}\end{array}$ & $\begin{array}{c}\text { Ref. }{ }^{16} ; 1 \mathrm{M} \mathrm{LiPF}_{6} \\
\text { in } \mathrm{EC} / \mathrm{DMC}\end{array}$ \\
\hline $\begin{array}{l}\text { SiOC- } 1000^{\circ} \mathrm{C} \\
\text { microsized } \\
\text { particles }\end{array}$ & $\begin{array}{l}\text { DBD with CA } \\
\text { and PVdF } \\
\left(3-5 \mathrm{mg} \cdot \mathrm{cm}^{-2}\right)\end{array}$ & $\begin{array}{c}483 \\
\text { (am. 568) }\end{array}$ & $\begin{array}{l}246 \text { (am: } 290) \\
\text { at } 372 \mathrm{~mA} \cdot \mathrm{g}^{-1}\end{array}$ & $\begin{array}{l}\text { Ref. }^{8} ; 1 \mathrm{M} \mathrm{LiPF}_{6} \\
\text { in EC/DMC }\end{array}$ \\
\hline $\begin{array}{l}\text { SiOC- } 1300^{\circ} \mathrm{C} \\
\text { microsized } \\
\text { particles }\end{array}$ & $\begin{array}{l}\text { DBD with CA } \\
\text { and PVdF } \\
\left(3-5 \mathrm{mg} \cdot \mathrm{cm}^{-2}\right)\end{array}$ & $\begin{array}{c}250 \\
\text { (am. 293) }\end{array}$ & $\begin{array}{c}68 \text { (am: 80) at } \\
372 \mathrm{~mA} \cdot \mathrm{g}^{-1}\end{array}$ & $\begin{array}{l}\text { Ref. }{ }^{8} ; 1 \mathrm{M} \mathrm{LiPF}_{6} \\
\text { in EC/DMC }\end{array}$ \\
\hline $\begin{array}{l}\text { (low carbon) } \\
\text { SiOC- } 1300^{\circ} \mathrm{C} \\
\text { microsized } \\
\text { particles }\end{array}$ & $\begin{array}{l}\text { DBD with CA } \\
\text { and PVdF } \\
\left(3-5 \mathrm{mg} \cdot \mathrm{cm}^{-2}\right)\end{array}$ & $\begin{array}{c}619 \\
\text { (am. 728) }\end{array}$ & $\begin{array}{c}43 \text { (am: 50) at } \\
372 \mathrm{~mA} \cdot \mathrm{g}^{-1}\end{array}$ & $\begin{array}{l}\text { Ref. }^{8} ; 1 \mathrm{M} \mathrm{LiPF}_{6} \\
\text { in EC/DMC }\end{array}$ \\
\hline
\end{tabular}




\section{Figures}
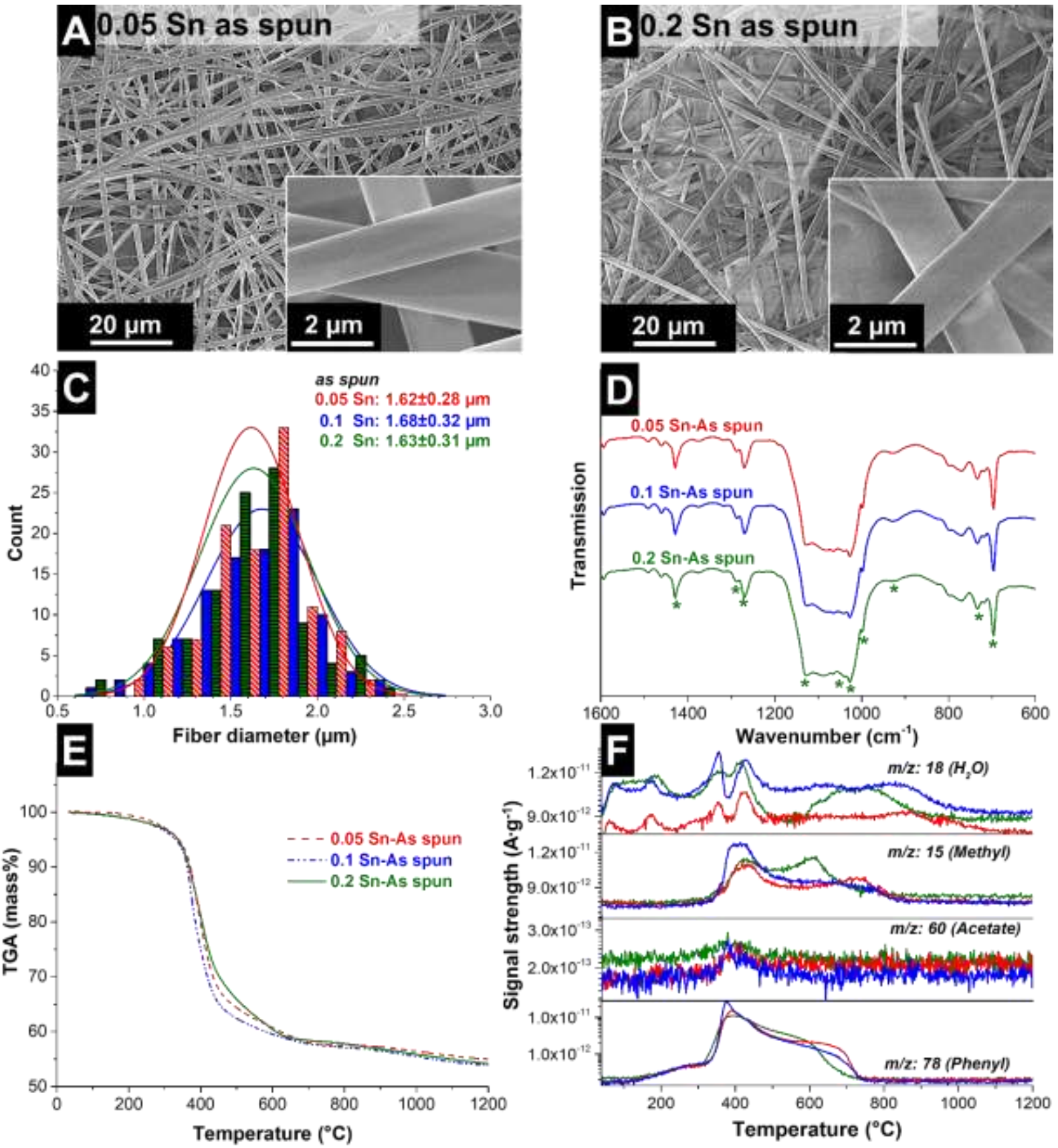

Figure 1: SEM micrographs of as spun silicon resin fibers containing $0.05 \mathrm{Sn}(\mathrm{A})$ and $0.2 \mathrm{Sn}(\mathrm{B})$.

Fiber diameter distribution (C) and Fourier transform infrared spectra (D) of the as spun fibers. Thermogravimetric analysis (E) and mass spectra of the most important moieties (F), during heat treatment under inert atmosphere of the as-spun fibers. 


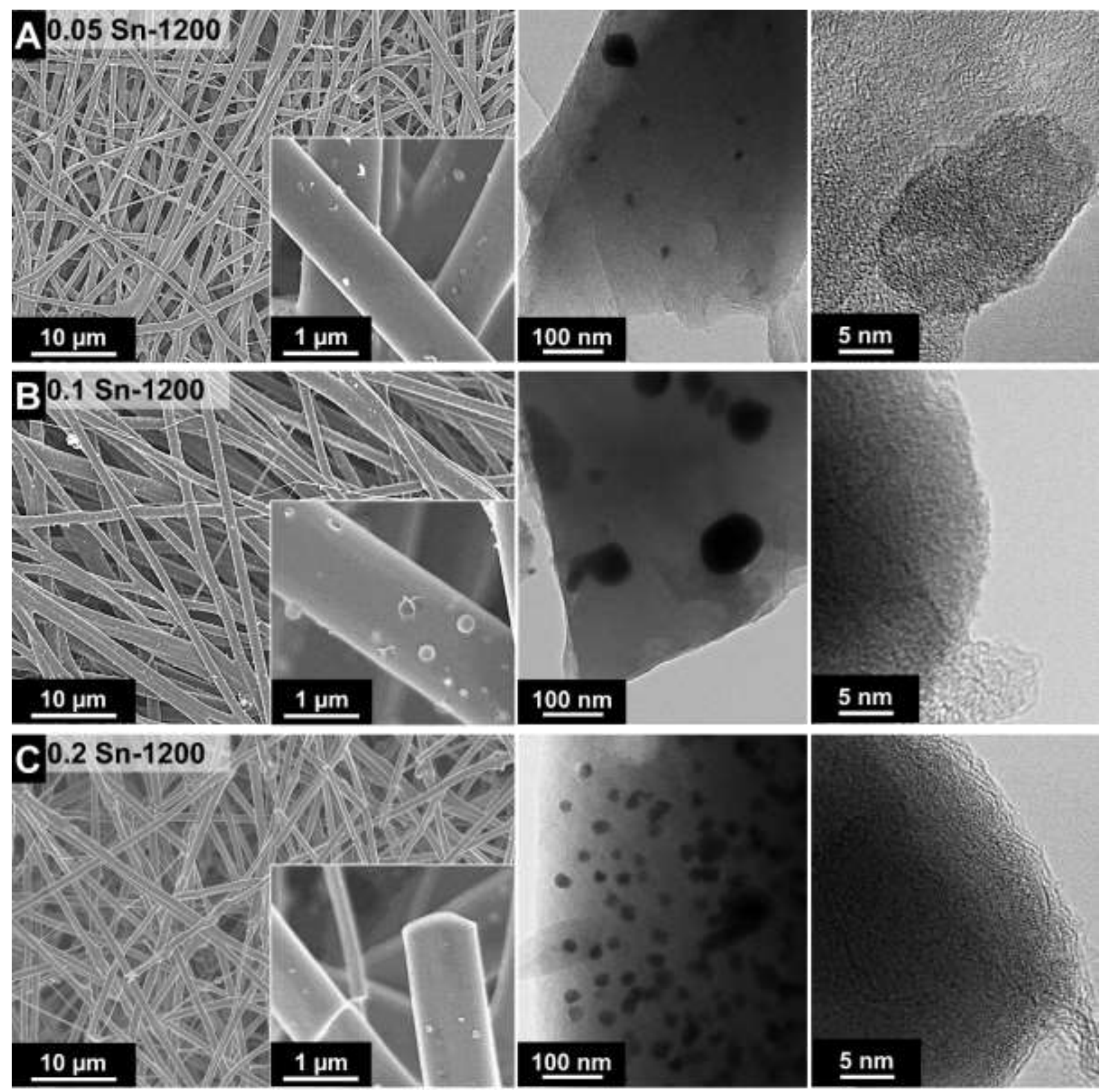

Figure 2: SEM and TEM micrographs (inset) of the SiOC fibers synthesized at $1200^{\circ} \mathrm{C}$, containing different amounts of Sn: 0.05 (A), 0.1 (B), and 0.2 (C). 

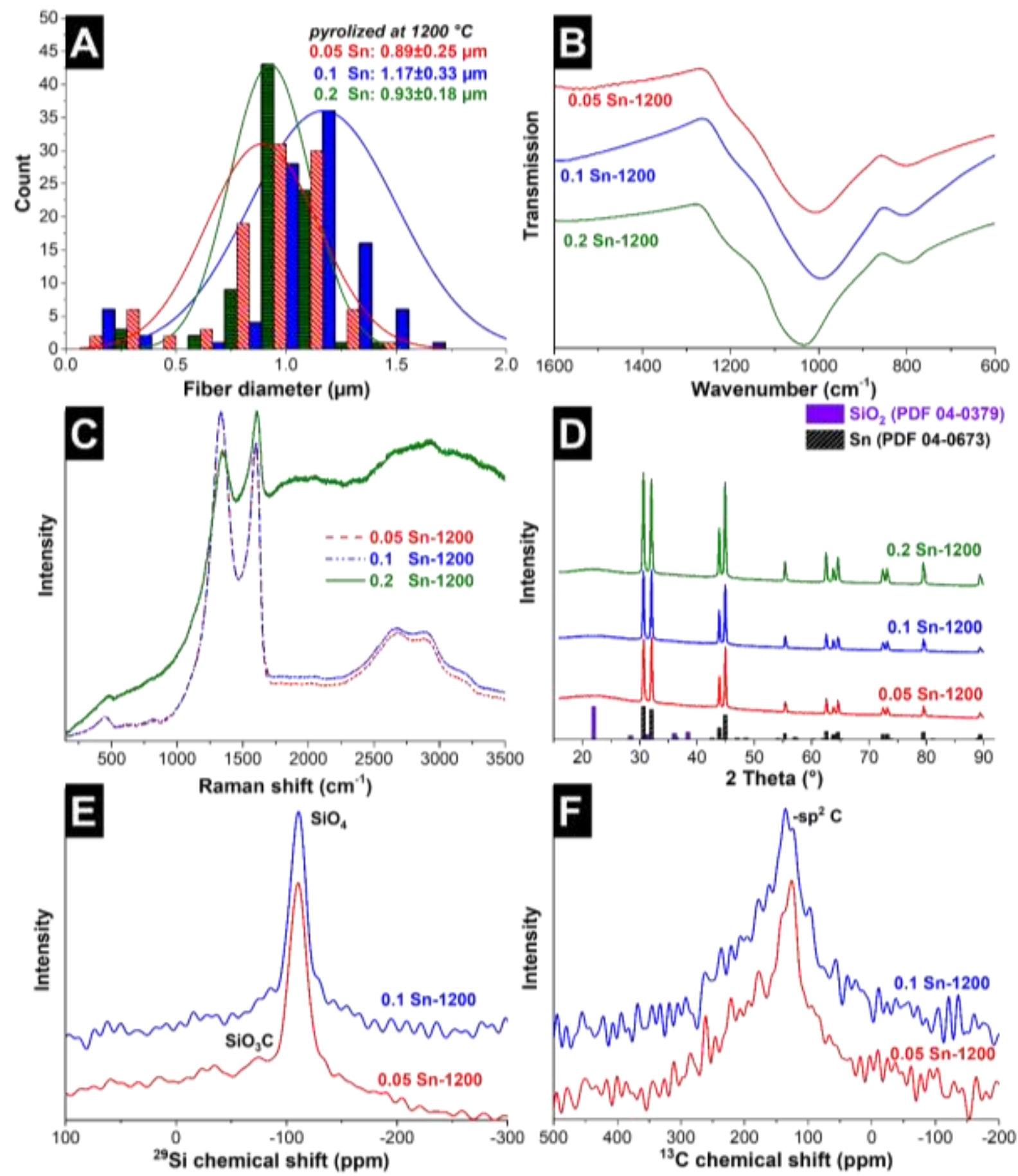

Figure 3: Material characterization of fibers synthesized at $1200^{\circ} \mathrm{C}$. Fiber diameter distribution (A), Fourier transform infrared spectra (B), Raman spectra (C), X-ray diffraction pattern and literature values for diffraction peak positions (D), solid-state ${ }^{29} \mathrm{Si} N \mathrm{NR}(\mathrm{E})$, and ${ }^{13}$ C NMR (F). 

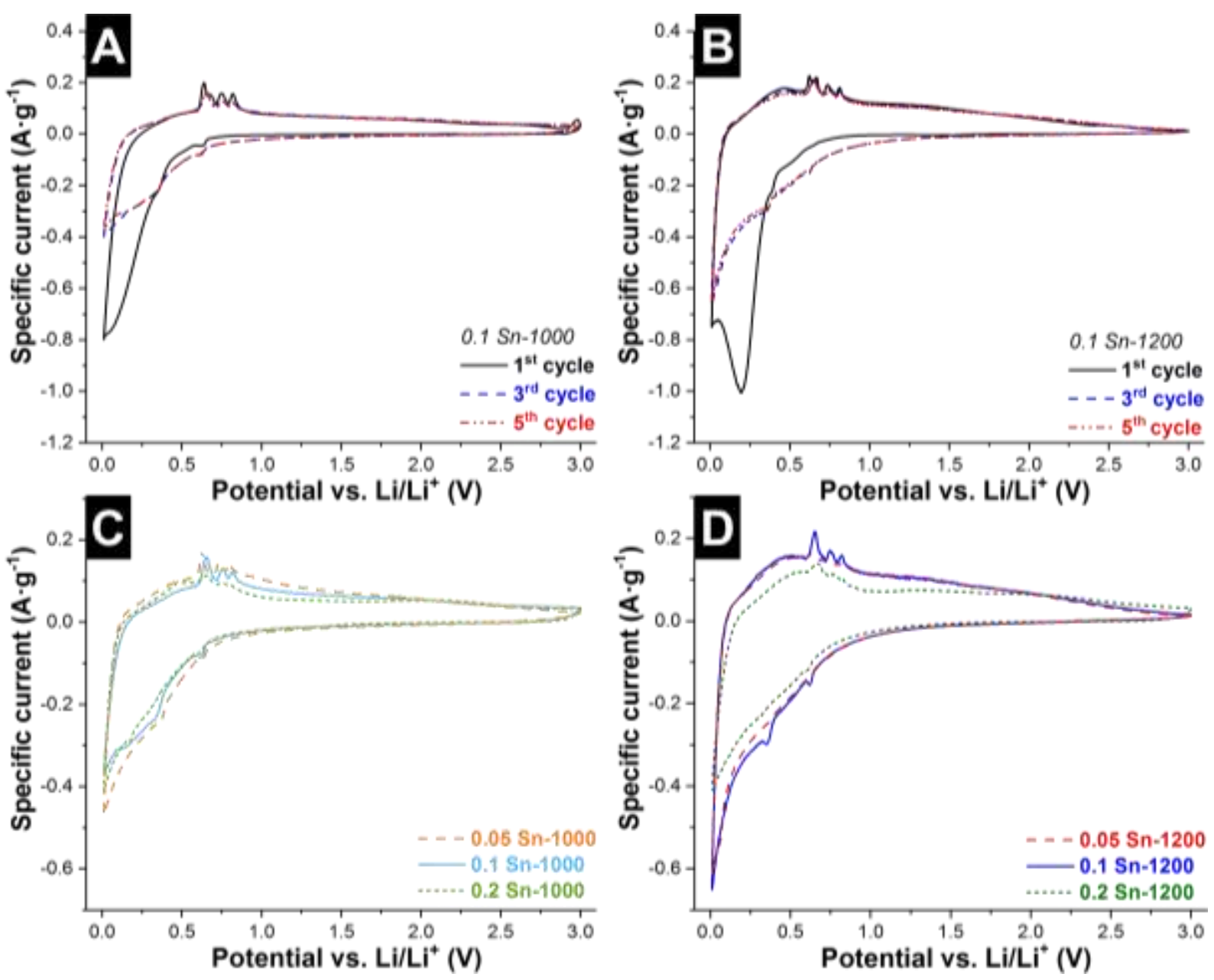

Figure 4: Electrochemical characterization in half-cell configuration of SiOC/Sn hybrid fibers by cyclic voltammetry at $0.1 \mathrm{mV} \cdot \mathrm{s}^{-1}$. First 5 cycles for the samples containing $0.1 \mathrm{Sn}$ synthesized at $1000{ }^{\circ} \mathrm{C}(\mathrm{A})$ and $1200{ }^{\circ} \mathrm{C}$ (B). $5^{\text {th }} \mathrm{Cycle}$ of the samples synthesized at $1000^{\circ} \mathrm{C}(\mathrm{C})$ and $1200{ }^{\circ} \mathrm{C}$ (D). 

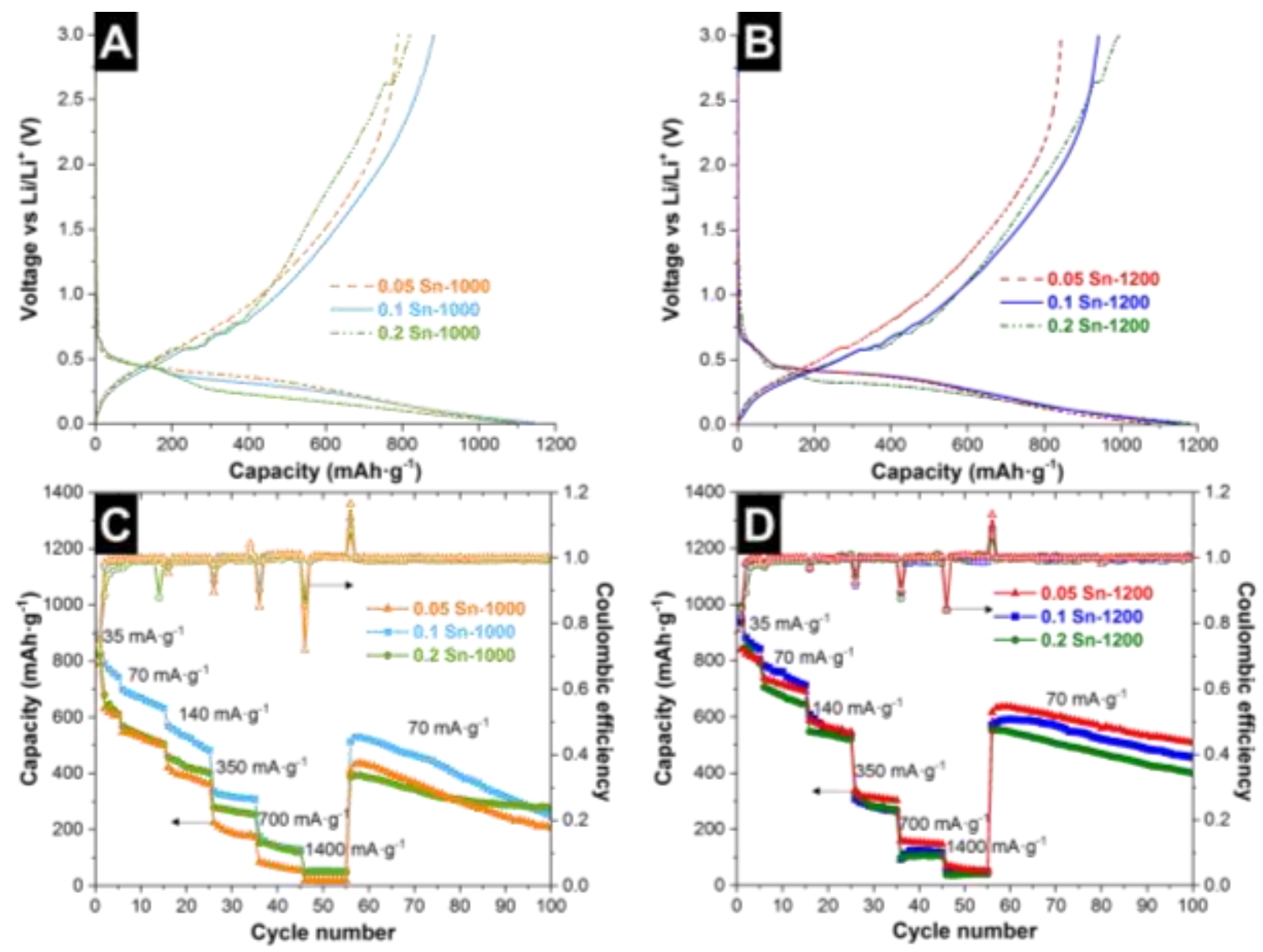

Figure 5: First cycle of galvanostatic lithiation/delithiation at $35 \mathrm{~mA} \cdot \mathrm{g}^{-1}$ from $3.0-0.01 \mathrm{~V} v \mathrm{~s}$. $\mathrm{Li} / \mathrm{Li}^{+}$, for SiOC/Sn hybrid fibers synthesized at $100{ }^{\circ} \mathrm{C}(\mathrm{A})$ and $1200{ }^{\circ} \mathrm{C}(\mathrm{B})$. Rate handling performance of samples synthesized at $1000^{\circ} \mathrm{C}(\mathrm{C})$ and $1200^{\circ} \mathrm{C}$ (D). 


\section{Graphical abstract}
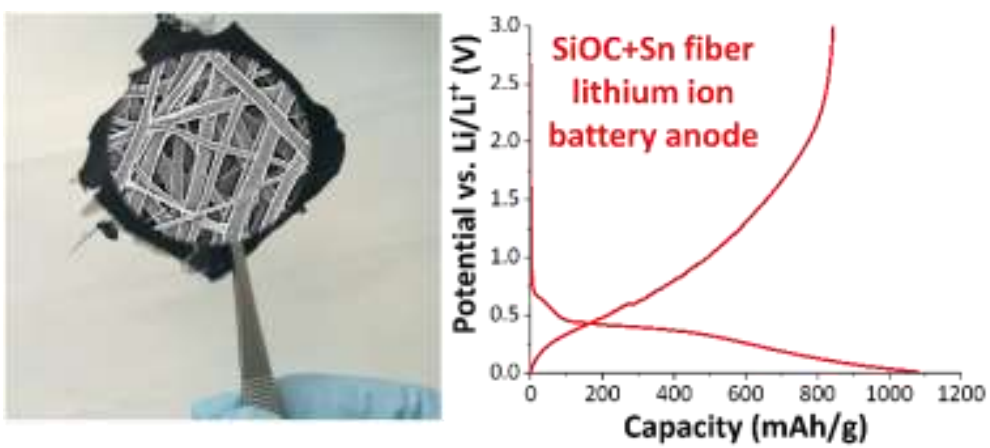